\title{
Lizards and amphisbaenians (Reptilia, Squamata) from the late Eocene of Sossís (Catalonia, Spain)
}

\author{
Arnau Bolet and Susan E. Evans
}

\begin{abstract}
A new diverse late Eocene lizard and amphisbaenian assemblage from the classical mammal locality of Sossís (Catalonia, Spain) is described. It represents the first Paleogene lizard assemblage from Spain and the first late Eocene lizard locality from the Iberian Peninsula. The family-level composition of the assemblage replicates that of other contemporaneous European localities, with the presence of iguanians, geckos, lacertids, scincids, cordyliforms, amphisbaenians, anguines, and glyptosaurines. Many of these families still occur in Catalonia, but the presence of thermophilic taxa like iguanians and cordyliforms are indicative of warmer conditions during the Eocene. The closest faunal match is with the contemporaneous French localities of the Phosphorites du Quercy. Sossís and other newly recovered Paleogene Spanish squamate assemblages have the potential to contribute to an understanding of patterns of faunal interchange between different Paleogene bioprovinces, complementing existing data on mammals.
\end{abstract}

Arnau Bolet. Institut Català de Paleontologia Miquel Crusafont/Universitat Autònoma de Barcelona, Escola Industrial 23, Sabadell, 08201, Catalunya, Spain. arnau.bolet@icp.cat

Susan E. Evans. Department of Cell and Developmental Biology, University College London. Gower Street, London WC1E 6BT, UK. ucgasue@ucl.ac.uk

Keywords: Squamata; lizards; amphisbaenians; Eocene; Iberian Peninsula; Spain

\section{INTRODUCTION}

Eocene European lizard faunas are relatively well known from France, Germany, Switzerland, and England (Figure 1; e.g., Augé, 2005; Rage and Augé, 2010; Klembara and Green, 2010). However, the Iberian record has been limited to the early Eocene (MP7) Portuguese assemblage of Silveirinha (Rage and Augé, 2003), which is also the only described Paleogene herpetofauna from southern Europe. The late Eocene Sossís fossilsite (Graus-Tremp basin, Catalonia) has been known since the 1940s (see Casanovas et al., 1998 and Checa and Casanovas, 1990 for historical background) and contains one of the best known mammal assemblages of the continental late Eocene of the Iberian Peninsula (see Cuesta et al., 2006 for artiodactyls, and López-Martínez et al., 1998 for a revision of the remaining mammal fauna). Despite mention of indeterminate croco- 


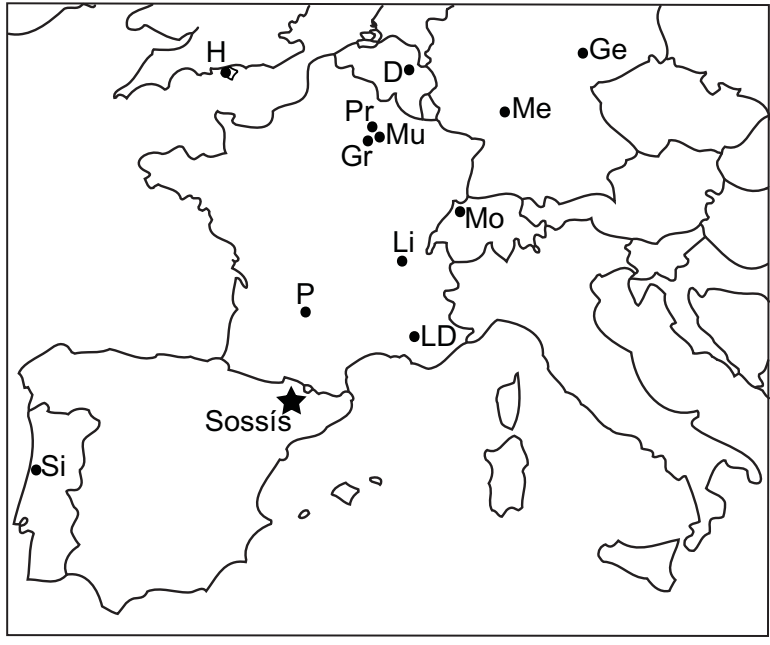

FIGURE 1. Map of southwestern Europe showing the main Eocene and Oligocene localities cited in the text. Abbreviations correspond to D: Dormaal; Ge: Geiseltal; Gr: Grisolles; H: Headon Hill; LD: La Débruge; Li: Lissieu; Me: Messel; Mo: Mormont-Entreroches; Mu: Mutigny; P: Phosphorites du Quercy (comprising the following localities, among others: Escamps, Lavergne, La Bouffie, Le Bretou, Les Pradigues, Malpérié, Perrière, Pech-du-Fraysse, Rosières and St. Néboule); Pr: Prémontré; Si: Silveirinha. For the exact age of each locality see the text.

diles (e.g., Berg and Crusafont, 1970) and turtles, the herpetofauna of the site has never been described in detail. In the 1990s, screen-washing efforts in the search for primates (currently under study [Marigó et al., in press]) yielded an important herpetofauna represented by thousands of isolated elements (tooth-bearing bones, skull bones, vertebrae, and osteoderms). In addition to the lizards, described here for the first time, the collection contains amphibians (frogs and salamanders), crocodiles, turtles, and snakes, which will be described elsewhere. This is the first Eocene lizard assemblage described from Spain, and the first late Eocene lizard assemblage from southern Europe.

\section{GEOLOGICAL SETTING}

Sossís is located in the Pobla de Segur subbasin, within the Graus-Tremp basin, which is one of the two Southern Pyrenean Basins (Cuesta et al., 2006). The Sossís lacustrine basin contains several fossiliferous levels at three localities: Roc de Santa, Sossís, and Claverol (Cuenca-Bescós, 1998). These levels have been correlated with Headonian levels from Montmartre (France, MP17a; Sigé, 1997), based on the presence of the rodent Theridomys euzetensis (Peláez-Campomanes, 1998).

\section{MATERIAL AND METHODS}

The material described here comes from a screen-washing concentrate obtained by researchers from the former Institut de Paleontologia de Sabadell (now Institut Català de Paleontologia Miquel Crusafont). The initial work focused on mammals, particularly small primates that had previously been reported by Crusafont $(1965,1967)$ and Crusafont and Golpe-Posse (1974). Consequently, the concentrate had only partially been processed and the herpetological material was not picked out or described. The restudy of the concentrates has revealed abundant herpetological remains, most of which are disarticulated except for some snake vertebrae. As the specimens come exclusively from screen-washing, the material is more fragmentary than if it had been surface collected or quarried, but it provides a better representation of the high diversity of small vertebrates, most of which are very small. The following isolated elements are described: frontals, parietals, premaxillae, maxillae, dentaries, vertebrae, and osteoderms. We have followed established criteria, recently formalised by Smith (2009a), in order to associate specimens: the specimens were secondarily associated with one another (considered to represent the same species) on the basis of size, abundance, apomorphies, complementarity of articulation, and other more or less direct data, such as surface ornamentation. These criteria have to be combined, as far as possible, in order to avoid the misassociation of elements of different taxa. In a well-sampled site such as Sossís, the represented taxa will each have a common size range, but the relative size of the morphotypes will not be always decisive on its own. Relative abundance can be used, with caution, to associate two common morphotypes or, on the contrary, two poorly represented morphotypes. Although complementarity of articular surfaces can provide relatively direct evidence for association of two elements, well-preserved articulation surfaces are rare in the Sossís collection. The strongest evidence for association comes from the similarity of dermal sculpture. Photographs were taken with an Environmental Scanning Electron Microscope. The material described herein is housed at the Institut Català de Paleontologia Miquel Crusafont, labelled IPS followed by the corresponding number. 


\section{Institutional and Other Abbreviations}

IPS, Institut de Paleontologia de Sabadell (now Institut Català de Paleontologia Miquel Crusafont); QU, Phosphorites de Quercy, Muséum national d'Histoire naturelle; USTL, Université des Sciences et Techniques du Languedoc; MP, Mammal Paleogene reference level

\section{SYSTEMATIC PALEONTOLOGY}

Squamata Oppel, 1811

Higher-level relationships within squamates are still not resolved, with a conflict between morphology based trees (e.g., Estes et al., 1988; Conrad, 2008; Gauthier et al., 2012) and those based on molecular or combined data sets (e.g., Townsend et al., 2004; Vidal and Hedges, 2005; Wiens et al., 2006, 2010, 2012; Conrad et al., 2010; Müller et al., 2011). However, most of these analyses support the monophyly of the same major squamate groups: Iguania, Gekkota, Dibamidae, Scincoidea, Anguimorpha, Serpentes, and Lacertiformes, the latter clade encompassing Amphisbaenia in molecular (e.g., Townsend et al., 2004; Wiens et al., 2012) and combined evidence (Wiens et al., 2006, 2010; Müller et al., 2011) trees, but not those derived from morphology alone (e.g., Estes et al., 1988; Conrad, 2008; Gauthier et al., 2012). Gauthier et al. (2012) use the alternative name Lacertoidea for this clade but previous authors (e.g., Estes et al., 1988; Conrad, 2008) applied Lacertoidea to a larger clade that included xantusiids, a group now more often placed with scincoids (e.g., Vicario et al., 2003; Gauthier et al., 2012; Wiens et al., 2012). Vidal and Hedges (2005) also grouped amphisbaenians with lacertids, teiids, and gymnophthalmids, but unnecessarily erected a new clade name, Laterata. The monophyly of Scleroglossa (all squamates except Iguania), Scincomorpha (lacertiforms and scincoids) and Autarchoglossa (non-gekkotan, non-iguanian squamates) is not generally supported in molecular trees. We have therefore avoided these higher clade names until the relationships are clarified and a consensus is reached. In some cases, and because the European record is reasonably well known, comparisons have been focused on European taxa, and identifications are thus subject to geographic restrictions.

Iguania Cuvier, 1817

Iguanidae Gray, 1827

Three pleurodont iguanian genera, Carduciguana (Augé, 1987; MP16-19, France), Gei- seltaliellus (Kuhn, 1944; MP7, Belgium, Portugal; Augé, 2005; Augé and Pouit, 2012; MP8-10, MP16-19, MP28, France; Rossmann, 2000a; MP11-12, Germany) and Pseudolacerta (De Stefano, 1903, MP16-19, France) have been reported from the European Paleogene. All of these taxa have tricuspid teeth, a characteristic shared by several of the Sossís specimens. Among extant lizards, tricuspidy is also found in lacertids and teiids, but teiids usually have cementum at the base of the tooth and among Eocene lacertids, tricuspid teeth are found only in Plesiolacerta lydekkeri. In that species, a weak third cusp results in an asymmetric tooth shape, and the grooves separating the main cusp from the accessory cusps are developed lingually but not labially (Augé, 2005). This morphology does not match any of the tricuspid jaw fragments from Sossís which more closely resemble those of Geiseltaliellus and Pseudolacerta.

Genus Geiseltaliellus Kuhn, 1944 Geiseltaliellus pradiguensis Augé, 2007

Material: IPS 56093 (Figure 2.1), partial right dentary with four preserved teeth; IPS 56094, partial right maxilla with one broken and three complete teeth; IPS 59521, fragment of ?dentary with five teeth (Figure 2.2); less certainly IPS 59523, five fragments of ?dentaries with teeth.

Description: The identified elements have exceptionally tall pleurodont tricuspid teeth, projecting only slightly above the parapet of the dentary. The teeth are slightly posteriorly inclined, but due to the deformation of the specimens this feature is of doubtful value. A mesiodistal constriction of the crown seems to characterize most teeth.

Remarks: Geiseltaliellus is known from the early to late Eocene (MP7-19; Augé, 2007) of Europe, with a single post-Grande Coupure record at Pech-duFraysse (France, Phosphorites du Quercy, MP28; Augé and Pouit, 2012). Geiseltaliellus pradiguensis (France, Les Pradigues, MP17) differs from other G. species in having tall, slender teeth that project only one fifth of their height above the jaw parapet (one third in the other Geiseltaliellus species, Augé, 2007). The teeth of the Sossís material are straight and slightly posteriorly inclined, and the exceptionally tall teeth are clearly reminiscent of Geiseltaliellus species.

\section{Geiseltaliellus sp.}

Material: IPS 56090 (Figure 2.3), partial left dentary with eight complete and four broken teeth.

Description: This well-preserved specimen (IPS 56090 ) is a partial left dentary broken into two 


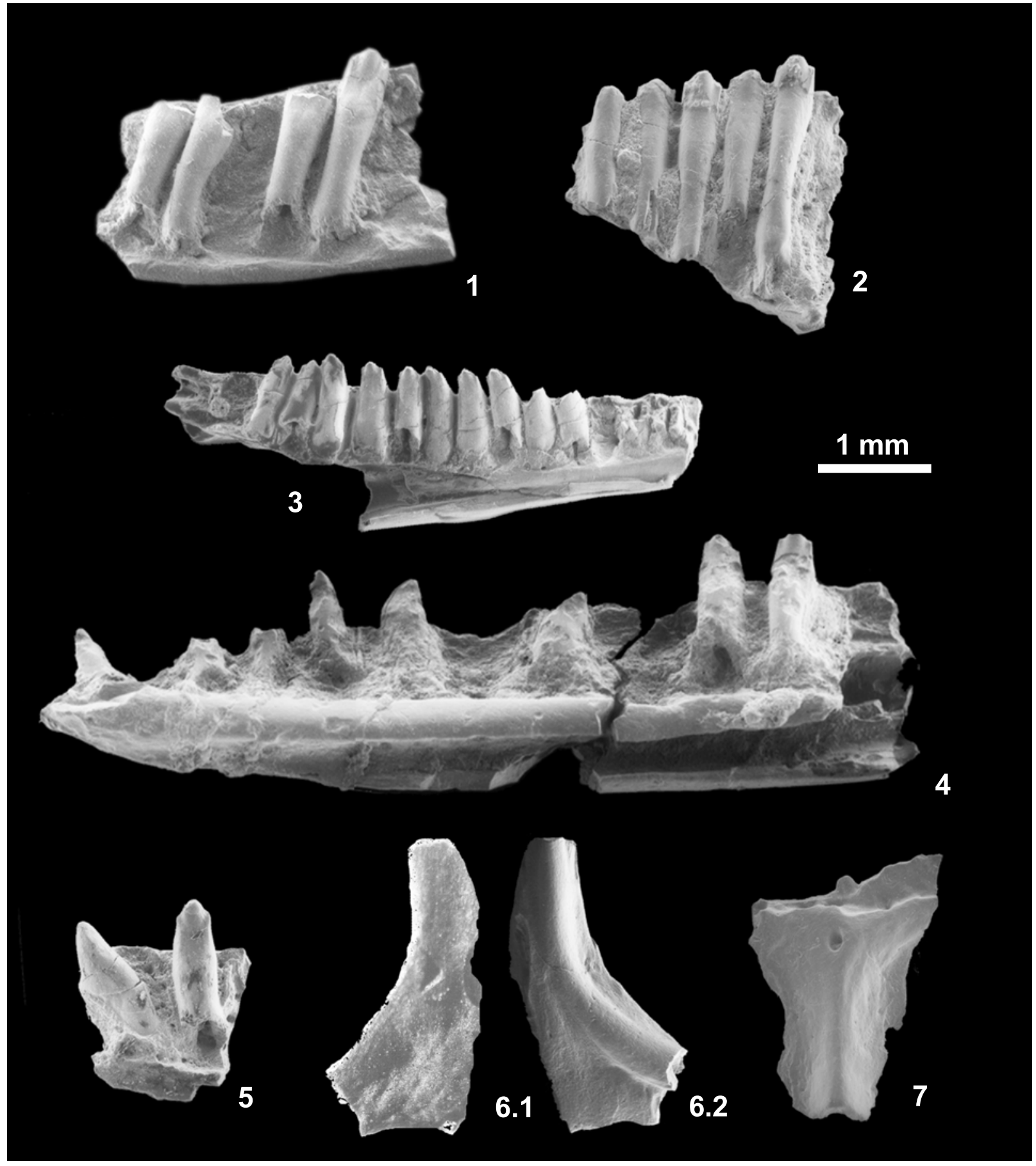

FIGURE 2. Pleurodont iguanians from the Sossís locality. 1, 2: Geiseltaliellus pradiguensis. 1- fragment of right dentary in lingual view (IPS 56093); 2- fragment of ?dentary in lingual view (IPS 59521). 3: Geiseltaliellus sp. Partial left dentary in lingual view (IPS 56090). 4, 5: Pseudolacerta sp. 4- Partial right dentary in lingual view (IPS 56164); 5fragment of right dentary in lingual view (IPS 56165). 6-7: ? Iguanidae indet. 6- partial frontal in dorsal (6.1) and ventral (6.2) views (IPS 56109); 7- partial parietal in dorsal view (IPS 56091).

pieces and lacking the symphysial region. The ventral margin of the bone is straight. The Meckelian canal is wide open posteriorly, but becomes narrow with converging margins anteriorly. The splenial obscures this region and it is difficult to assess whether the two margins make contact, but fusion of the bone is certainly absent. The subdental shelf is moderately developed, with a rather rounded lin- 
gual surface and lacking a sulcus dentalis. The dentary presents a short posterolingual facet for the anterior process of the coronoid, and preserves eight complete teeth, with two additional broken bases, and three empty positions at the back and front of the bone. The implantation is pleurodont and the teeth are high-crowned, with one-third of their height projecting above the parapet. The crowns are clearly tricuspid, with a strong central cusp flanked by smaller cusps. As preserved, the teeth are slightly recurved, with tapered tips and somewhat enlarged bases. The teeth are perpendicular to the long axis of the bone in the middle part of the tooth row but have a tendency to incline slightly posteriorly in the anterior part of the tooth row and slightly anteriorly in posterior tooth positions. There is a large labial foramen at the middle height of the dentary, at the level of the first broken tooth.

Remarks: This material is referable to Geiseltaliellus on the basis of the dentary morphology: the Meckelian canal is closed and fused in Cadurciguana and has parallel borders in Pseudolacerta. IPS 56090 also lacks the enlarged anterior caniniform teeth typical of Pseudolacerta. It is clearly different from the $G$. pradiguensis specimen described above in having much shorter teeth. If the specimen is adult, the species would lie at the lower end of the size range of the genus. The presence of two species of Geiseltaliellus in the same deposit is common in European Eocene sites (e.g., at the French localities of Grisolles, Malpérié and Les Pradigues; Augé, 2005).

\section{Genus Pseudolacerta De Stefano, 1903 Pseudolacerta sp.}

Material: IPS 56164 (Figure 2.4), a partial right dentary with five complete and three broken teeth; IPS 56165, a fragment of dentary with two teeth (Figure 2.5); and less certainly, IPS 56152, anterior part of a right dentary with 5 broken teeth.

Description: IPS 56164 is a right dentary lacking only its posterior end. The bone is straight and rather slender. The subdental shelf is rounded and there is no sulcus dentalis. The Meckelian canal has parallel margins, but the opening extends from posterolingual to anteroventral. The dentition is heterodont, with enlarged anterior caniniform teeth, and slender posterior tricuspid teeth. IPS 56165 is interpreted as bearing the last caniniform and the first tricuspid teeth of a smaller specimen of the same taxon. IPS 56152 is an anterior part of dentary presenting large, probably, caniniform teeth (mostly broken). All three specimens are tentatively referred to Pseudolacerta.
Remarks: Among Eocene iguanians, a heterodont dentition, with large anterior caniniform teeth and slender posterior tricuspid teeth, is only known for Pseudolacerta. Both known species (Pseudolacerta mucronata and Pseudolacerta quercyini) are known from MP17 horizons at Les Pradigues, France (Augé, 2005), but the Sossís material more closely resembles $P$. quercyini in its smaller size, its weaker anterior caniniform teeth, its straight dentary margin and dental platform (parallel margins of Meckelian canal), and the more slender anterior dentary. Pseudolacerta lamandini (Filhol, 1877; MP17-19, France) was recently transferred to the genus Geiseltaliellus (Augé, 2005). This species has a dentary morphology reminiscent of Pseudolacerta, although the caniniform shape of the anterior teeth is less marked. Moreover, the transfer of $P$. lamandini to Geiseltaliellus remains unsettled (Smith, 2009b). We tentatively refer the Sossís material to Pseudolacerta sp., but $P$. mucronata can be eliminated due to its massive caniniform teeth. Dentaries of the other recorded European iguanian, Cadurciguana, combine a closed and fused Meckelian canal with tricuspid teeth. Such dentaries are absent at Sossís.

Additional Pleurodont Iguanian Material

The remaining specimens are difficult to assign as they lack diagnostic characters and could belong to either Geiseltaliellus or Pseudolacerta or to an additional taxon.

Material: IPS 49853, IPS 56092, IPS 5613856144, IPS 56230, IPS 56232, IPS 59481, IPS 59501, IPS 59506, IPS 59522, tooth-bearing bone fragments; ?IPS 56109, partial frontal (Figure 2.6); ?IPS 56091, partial parietal (Figure 2.7).

Remarks: With the exception of anterior dentary specimens and more or less complete dentaries, most tooth-bearing bones with tricuspid teeth cannot be referred to a discrete pleurodont iguanian taxon. They probably belong to Pseudolacerta and Geiseltaliellus, but the presence of additional taxa cannot be discounted. IPS 56109 is a partial fused frontal resembling that of Geiseltaliellus, but its fragmentary nature precludes precise attribution. The cristae cranii are weakly developed and do not meet each other ventrally. A subtle ornamentation is present on the dorsal surface of the bone.

IPS 56091 is the anterior part of a small parietal that can be referred tentatively to Iguania. It is clearly different from the known parietals of Geiseltaliellus in that the parietal foramen is close to the frontoparietal suture but still within the parietal. It also differs from Cadurciguana, in which the parietal foramen lies at the frontoparietal suture. The 


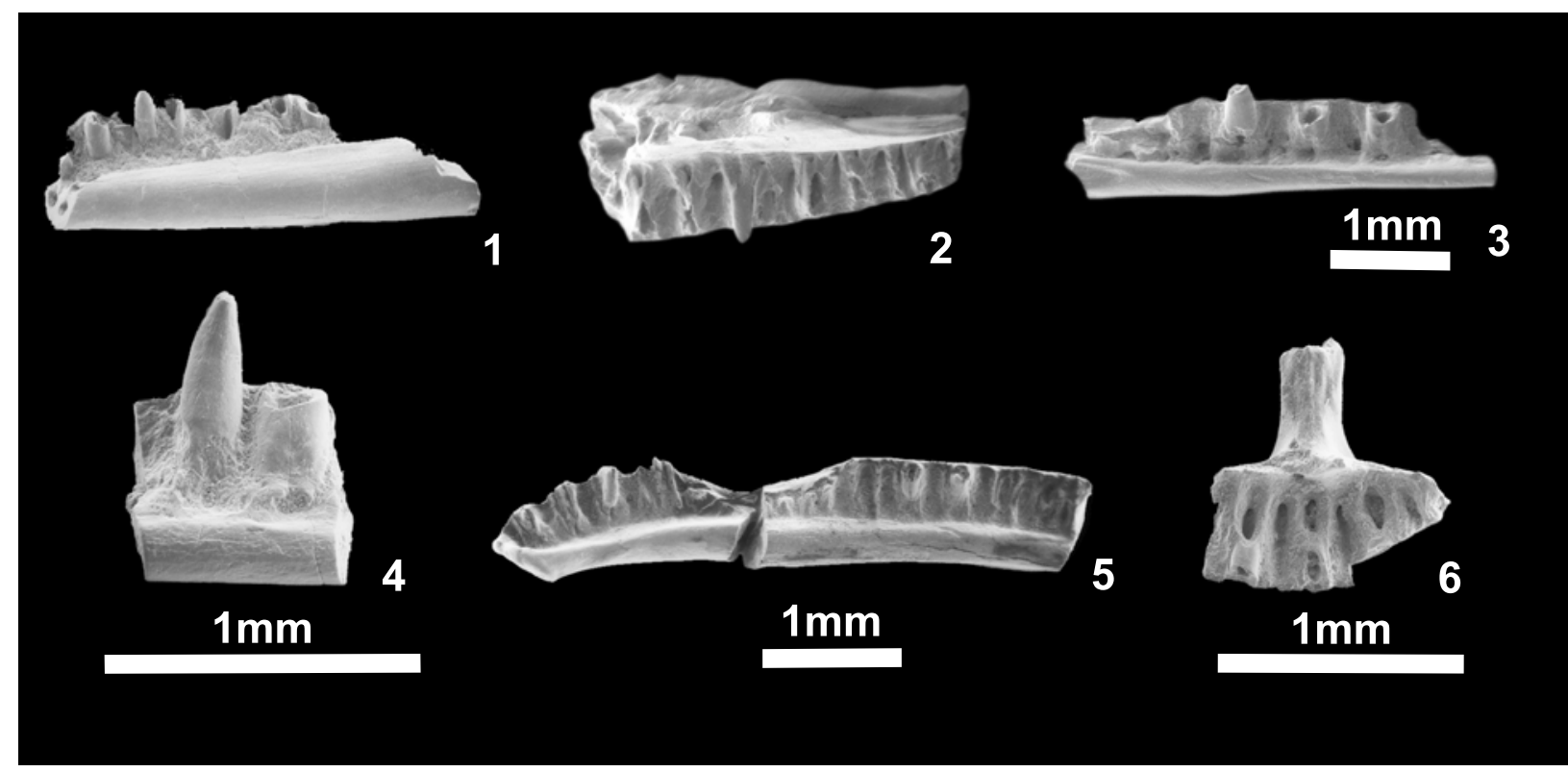

FIGURE 3. Gekkotan material from the Sossís locality. 1, 2: Gekkota indet. Form A. 1- partial right dentary in lingual view (IPS 56178); 2- partial right maxilla in lingual view (IPS 56065). 3, 4: Gekkota indet. Form B. 3- partial left dentary in lingual view (IPS 56132); 4- fragment of right dentary in lingual view (IPS 56116). 5: Gekkota indet. Form C. Partial right dentary in lingual view (IPS 56173). 6: Gekkota indet. Premaxilla in lingual view (IPS 59478).

parietal of Pseudolacerta is unknown. The occurence of the parietal foramen within the parietal is the common condition in non-iguanian lizards but it is rare in iguanians, with the exception of some polychrotines (Evans, 2008). Comparison of IPS 56091 with the parietal of Geiseltaliellus (e.g., Smith, 2009b) and its living relatives, the corytophanines (e.g., Smith, 2011), highlights marked differences, and therefore the identification of this bone as iguanian is only tentative.

\section{Gekkota Cuvier, 1817}

The presence of three clearly different types of slender dentary with a closed and fused Meckelian canal and numerous teeth has allowed the identification of three different, but currently indeterminate, gekkotans. Gekkotan remains are relatively rare in the fossil record as these lizards are generally gracile with thin bones. In the Paleogene of Europe, the following genera are recognized: Laonogekko (Augé, 2003; France: Prémontré, MP10), Cadurcogekko (Hoffstetter, 1946; France: many localities, MP 16-19), Rhodanogekko (Hoffstetter, 1946; Rage and Augé, 2010; France: Lissieu, MP14). Indeterminate gekkotan material has been reported from the early and late Eocene of France and Belgium (Augé, 2005). The absence of gekkotans from most middle Eocene localities is probably linked to the fact that levels at Geiseltal and Messel (Germany) usually yield large lizards
(Augé, 2005). The few Middle Eocene gekkotans known are from localities that have yielded lizard remains through screen-washing (e.g., Lissieu, MP14 and Le Bretou, MP16; Augé, 2005; Rage and Augé, 2010).

\section{Gekkota indet. Form A}

Material: IPS 56176, partial right dentary with one preserved tooth; IPS 56178, partial right dentary with one preserved tooth (Figure 3.1); IPS 56065, partial right maxilla with one preserved tooth (Figure 3.2).

Description: Small unicuspid, cylindrical, and closely spaced teeth unite the maxilla and partial dentaries associated in this form. These dentaries are a little more robust than those of the other gekkotans from the site. The dentaries are also characterized by a well-developed subdental shelf that becomes shallower anteriorly. The Meckelian canal is completely closed and fused, and a sulcus dentalis is present and anteriorly deep. The teeth are smaller and much more closely packed, cylindrical and slender than those in Form B. Note that the presence of a second transversely positioned cusp cannot be evaluated in these specimens because preserved tooth crowns are worn.

\section{Gekkota indet. Form B.}

Material: IPS 56132, partial left dentary with one preserved tooth (Figure 3.3); IPS 56116, fragment 
of right dentary with one preserved tooth (Figure 3.4); IPS 56133, fragment of left dentary; IPS 56172, partial right dentary with three broken teeth; IPS 56182, fragment of right dentary; IPS 56183, anterior portion of right dentary with one preserved tooth; IPS 56184, fragment of right dentary with two broken teeth; IPS 56185, anterior portion of right dentary; IPS 56186, fragment of ?right dentary with two broken teeth; IPS 56187, fragment of right dentary with two broken teeth; IPS 56188, fragment of ?right dentary; IPS 56192, anterior portion of right dentary with three broken teeth; IPS 59499 , fragment of dentary with one broken tooth; IPS 59511, partial dentaries and fragments of dentaries.

Description: This second form is characterized by teeth that are more robust, slightly labiolingually compressed, and more widely spaced. The internal face of the crown is flat, without any striations, and the tip bears a second cusp situated in a lingual position, resulting in two parallel crests. Although none of the dentaries is complete, the tooth count would presumably have been much lower in Form $B$ than in Forms $A$ and $C$. The dentaries are also extremely slender, with a relatively shallow, rounded subdental shelf, the dorsal and ventral surfaces of which are almost parallel. The Meckelian canal is closed and fused. There is a short facet for the articulation of the splenial, but this is restricted to the posterior part of the dentary. A sulcus dentalis is absent.

\section{Gekkota indet. Form C.}

Material: IPS 56117, fragment of right dentary with one preserved tooth; IPS 56173, partial right dentary (Figure 3.5) with five broken teeth; IPS 56174, fragment of right dentary with two teeth; IPS 56175 , anterior region of a right dentary with six broken teeth; IPS 56177, partial right dentary with one preserved tooth; IPS 56180, fragment of ?left dentary with five broken teeth; IPS 56190, anterior portion of left dentary with three broken teeth.

Description: This form shares characters with Forms $A$ and $B$, but it is clearly different from both. The dentaries are long and slender, with a subdental shelf that has parallel dorsal and ventral surfaces (as in Form B), but teeth that are conical, small, numerous and closely packed as in Form A.

\section{Additional Gekkotan Material}

Material: IPS 59478, partial fused premaxilla (Figure 3.6); IPS-56114, left dentary fragment with two preserved teeth; IPS 56115, left dentary fragment with two teeth; IPS 56120, fragments of dentaries; IPS 56179, fragment of right dentary with four bro- ken teeth; IPS 56181, fragment of right dentary with four broken teeth; IPS 56189, fragment of dentary with two broken teeth; IPS 56191, fragments of dentaries; IPS 59520, fragments of dentaries.

Description: This small unpaired premaxilla shows the typical gekkotan T-shape. Its dorsal process appears rather slender. The lateral processes are straight and at $90^{\circ}$ to the nasal process. The tips of the lateral processes are broken, but a minimum of nine tooth positions is interpreted. The tooth crowns are all broken, so their morphology cannot be observed. This material cannot be attributed to any one of the gekkotan 'forms' outlined above.

Remarks: Diagnostic character states of fossil gekkotans are largely restricted to maxillae, premaxillae, and frontals. Unfortunately, only one partial maxilla, one partial premaxilla, and several partial dentaries are preserved among the Sossís material. Although this material demonstrates the presence of gekkotans at Sossís, the material is too fragmentary to make a more precise referral. Dentaries are the most abundant and recognisable Paleogene gekkotan bones, but they have not been characterized at generic level and the most useful elements are maxillae (Augé, 2005). Rhodanogekko is known only from a distinctive frontal from Lissieu, France (MP14; Hoffstetter, 1946), obviating comparison with the Sossís gekkotans as no frontal material is available. The overall shape of the maxilla and dentaries of Form A are similar to those of Laonogekko from Prémontré, France (MP10; Augé, 2005), but important comparative characters are missing. Based on dentaries, three different gekkotans can be recognized at Sossís. The extremely slender subdental shelf, absence of a sulcus dentalis, and tooth shape of Form $B$ seems to differentiate it not only from Sossís Forms $A$ and $C$, but also from the other described Eocene gekkotans Laonogekko (Prémontré, MP10) and Cadurcogekko (Hoffstetter, 1946, from the Phosphorites du Quercy, France, MP16-19; Augé, 2005). The dentary of Rhodanogekko is unknown. The premaxilla, IPS 59478 , differs from that of an indeterminate gekkotan described from Prémontré (Augé, 2005, figure 69 ) in having a more slender nasal process and a lower tooth count ( 9 v. 11+ in the Prémontré specimen, Augé, 2005).

\section{Lacertiformes Estes et al., 1988 Lacertidae Bonaparte, 1831}

Lacertids are a constant component of the Cenozoic European faunas, and are known from most 
Eocene localities. The following characters are considered as suggestive of lacertid affinity (Augé, 2005): heterodont dentition with pleurodont anterior unicuspid and posterior bicuspid teeth; dentary ventral margin and subdental shelf ventrally arched; a Meckelian canal that is wide posteriorly but narrows towards the symphysis; and a splenial facet that almost reaches the symphysis. In many squamates, including lacertiforms, the coronoid has a lateral lappet that overlies the postero-labial surface of the dentary. Its presence in lacertiforms differentiates them from most scincoids, in which a postero-labial process of the dentary overlaps the coronoid (Augé, 2005). A number of the Sossís small dentaries can be attributed to Lacertidae based on this combination of characters. Only five species of Eocene lacertids fall in a similar size range: Gracilicerta sindexi (France, MP16-19, Augé, 2005); Dormaalisaurus girardoti (France and Belgium, MP7-16, Augé and Smith, 2002); Dormaalisaurus rossmanni (France and Belgium, MP7-10, Augé and Smith, 2002); Succinilacerta succinea (Baltic amber, Lithuania and Poland, MP13, Boulenger, 1917; Borsuk-Białynicka et al., 1999); and Escampcerta amblyodonta (France: La Bouffie, MP17; Escamps, MP19; Augé, 2005). Of these, Succinilacerta succinea (Boulenger, 1917) is known only from amber specimens and cannot be compared directly with the other taxa. In comparing the small Sossís lacertids to Dormaalisaurus and Gracilicerta, two characters, the presence or absence of striae and the degree of development of the small second cusp, were most useful in differentiating between genera and species in fragmentary specimens. Escampcerta amblyodonta differs in having a posterior amblyodont dentition, as do the larger Pseudeumeces, Cernaycerta, Dracaenosaurus and Quercycerta (Augé, 2005).

Genus Dormaalisaurus Augé and Smith, 2002 Dormaalisaurus rossmanni Augé and Smith, 2002

Material: IPS 59524, partial left dentary with four preserved teeth (Figure 4.1); IPS 56048 (Figure 4.2), partial right maxilla with six preserved teeth; IPS 56049, partial right maxilla with four preserved teeth; IPS 56060, four fragments of dentary with few preserved teeth; IPS 56089 partial right maxilla with three preserved teeth + partial left dentary with five broken teeth; IPS 56097, right dentary fragment with one tooth; IPS 56127, posterior fragment of left dentary with two preserved teeth.

Description: None of the specimens is complete, but tooth-bearing bones are united by the presence of labiolingually compressed teeth in which the second cusp is barely developed. The subdental shelf and the ventral margin of the dentary are only weakly curved (almost straight), and a deep sulcus dentalis is present. The maxilla lacks ornamentation at least on the preserved part of the labial surface, and the single preserved labial foramen is very large. The sulcus dentalis is narrow but rather deep.

Remarks: These elements are referred to Lacertidae on the basis of the tooth and dentary characters listed above. Among other characters, the presence of striae on the lingual surface of the crowns and a less developed second cusp differentiates Dormaalisaurus from Gracilicerta. Dormaalisaurus girardoti has a moderately developed second cusp, whereas in D. rossmanni the crowns are labiolingually compressed and there is no true second cusp. The presence and degree of development of striae on the lingual side of the crowns is variable, but is probably related to the degree of preservation.

Dormaalisaurus girardoti Augé and Smith, 2002

Material: IPS 56056, partial right dentary with two teeth (Figure 4.3); IPS 56051, fragment of left maxilla with four teeth; IPS 56054, fragment of right dentary with three preserved teeth; IPS 56059, anterior end of maxilla with two preserved teeth; IPS 59525, dentary and maxilla fragments.

Description: The subdental shelf and the ventral margin of the dentary are only weakly curved. The lingual surface of the subdental shelf is rounded. The crowns bear moderately developed cusps situated anterior to the main cusp. The crowns are lingually striated.

Remarks: The specimens referred to Dormaalisaurus girardoti differ from those of Gracilicerta sindexi (see below) in that the subdental shelf and the ventral margin of the dentary are less arched, and lingual striations are present on the crowns. They differ from specimens referred to $D$. rossmanni in the presence of a better developed second cusp. Some of these characters could be influenced by ontogeny, but until this is investigated in the betterknown material from France, we prefer to maintain the original taxonomic units and to refer our material on the basis of the characters previously described.

\section{Genus Gracilicerta Augé, 2005 \\ Gracilicerta sindexi Augé, 2005}

Material: IPS 56171, partial left dentary with eight preserved teeth (Figure 4.4); IPS 49854, fragment of left dentary with three preserved teeth; IPS 49856, fragment of left dentary with one preserved 


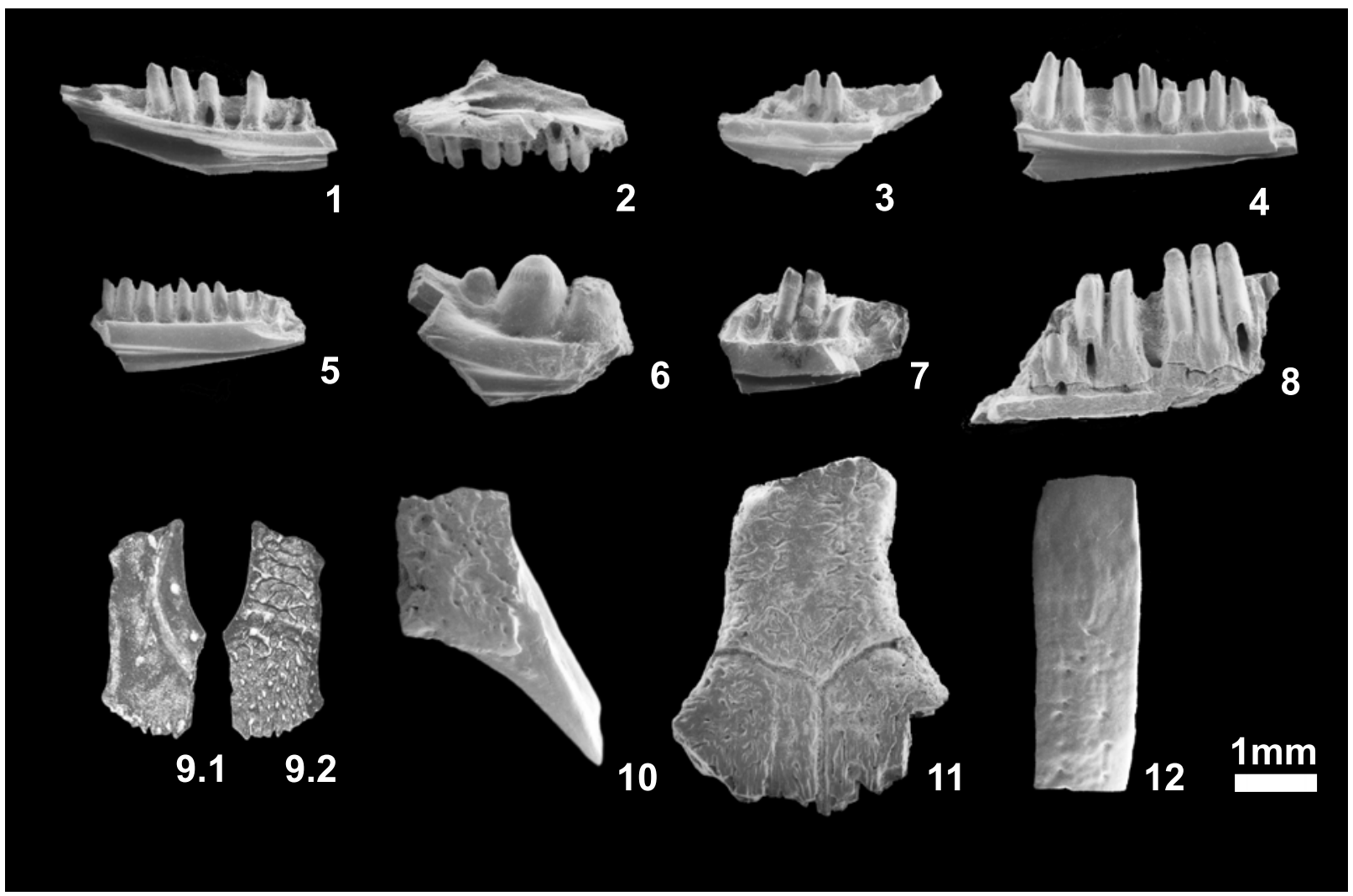

FIGURE 4. Lacertiforms and scincoids from the Sossís locality. 1, 2: Dormaalisaurus rossmanni. 1- partial left dentary in lingual view (IPS 59524); 2- partial right maxilla in lingual view (IPS 56048). 3: Dormaalisaurus girardoti, partial right dentary in lingual view (IPS 56056). 4: Gracilicerta sindexi, partial left dentary in lingual view (IPS 56171); 5: Lacertidae indet., fragment of left dentary in lingual view (IPS 56066); 6: ?Lacertidae (amblyodont form), fragment of left dentary in lingual view (IPS 56169); 7: ?Cordyliformes, fragment of left dentary in lingual view (IPS 56195); 8: ?Scincidae, fragment of dentary (IPS 56193); 9: Lacertidae indet. (IPS 56043). 9.1- left frontal in ventral view. 9.2- left frontal in dorsal view; 10: Lacertidae indet., posterior fragment of parietal in dorsal view (IPS 56046). 11: ?Lacertidae indet., fused frontal in dorsal view (IPS 56166). 12: Cordyliformes indet., body osteoderm in external view (IPS 49848a).

tooth; IPS 56050, fragment of left maxilla with two preserved teeth.

Description: The lingual face of the subdental shelf is flat all along the preserved portion. The ventral margin of the dentary is arched. The crowns bear a pointed, well-developed, and anteriorly positioned second cusp. A deep sulcus dentalis is present.

Remarks: As noted above, the dentary of Gracilicerta sindexi is differentiated from that of Dormaalisaurus species by the absence of striations on the tooth crowns, as well as the anteroventrally open Meckelian canal and a generally smaller size. The presence of a deep subdental shelf that leaves the Meckelian canal exposed only ventrally in the anterior part of the dentary, and the more arched general shape of the dentary supports attribution of IPS 56171 to this species. Compared to it, the den- tary of Dormaalisaurus shows a weaker bicuspidy and a less arched shape.

?Lacertidae indet. (amblyodont form)

Material: IPS 56169, fragment of left dentary with three preserved teeth (Figure 4.6); and, less certainly: IPS 56102, posterior left dentary fragment with two preserved teeth; ?IPS 56036, posterior left dentary fragment with two worn teeth; IPS 49913, right dentary fragment with two preserved teeth; IPS 56067, anterior portion of left maxilla with three preserved teeth; and IPS 56170, anterior portion of right maxilla with three preserved teeth.

Description: None of the tooth-bearing bones is complete but they certainly belonged to a shortjawed lizard. IPS 56169 (Figure 4.6) preserves the posteriormost three dentary teeth which are swollen and molariform (amblyodont) with well-defined 
lingual and labial striations. The subdental shelf is deep, but not prominent, and the lingual margin is flat. There is no sulcus dentalis, and small resorption pits are situated lingual to the base of each tooth. IPS 56102 and IPS 56036 (not figured) are smaller dentary fragments showing the same overall morphology: a deep subdental shelf, an enlarged amblyodont penultimate tooth, and a reduced last tooth. One right dentary fragment (IPS 49913, not figured) represents a more anterior jaw region and bears two labiolingually compressed but still amblyodont teeth, with highly worn crowns and small, lingually positioned, basal resorption pits. Two additional maxillary fragments (IPS 56067 and IPS 56170, not figured) are tentatively referred to the same taxon on the basis of tooth similarity.

Remarks: The tooth morphology of IPS 56169 is intermediate between that of moderately amblyodont lacertids such as Pseudeumeces Hoffstetter, 1944 and the much stronger amblyodonty of Dracaenosaurus Pomel, 1846. Dracaenosaurus ranges from MP28 to MP30 in France (Augé, 2005; Augé and Hervet, 2009), although there is one specimen (MNHN 1903-20), precise locality and age unknown, from old collections of the Phosphorites du Quercy. This latter specimen, the holotype of $D$. sauvagei (Filhol, 1882) but synonymised with $D$. croizeti (Augé, 2005), is from the late Eocene or, probably, the Oligocene (Augé, 2005). Hoffstetter (1944) used the presence of a small tooth posterior to the last molariform to differentiate $D$. sauvagei from $D$. croizeti, but Augé (2005) interpreted this as ontogenetic variation. The Sossís material shows some resemblance to Dracaenosaurus, but its smaller size and the weaker degree of amblyodonty suggest it is generically distinct. However, the available material is too poor to permit the erection of a new genus. Two additional amblyodont lacertids (Escampcerta amblyodonta and Quercycerta maxima) are known from the late Eocene of France (Augé, 2005), but the Sossís material differs from them in its much stronger amblyodonty, and the enlarged penultimate tooth. The amblyodont Sossís dentary fragments IPS 56036 and IPS 56102 are less amblyodont than IPS 56169, and also much smaller, but they show the same tendency towards an enlargement of the penultimate tooth. They are interpreted as juveniles of the same taxon as IPS 56169. They also resemble an unidentified left dentary (USTL Mal 606) from the MP17 level at Malpérie (France) (Augé, 2005, figure 206), although the latter's amblyodonty is less obvious due to wear. The small Sossís specimens and that from Malpérié may belong to the same taxon. IPS 49913, IPS 56067, and IPS 56170 are also amblyodont, but they correspond to regions (one dentary mid-section and two maxilla fragments) that cannot be directly compared to the other specimens, and they are less clearly related to them.

\section{Additional Lacertid Material}

Material: IPS 49855, eleven dentary fragments; IPS 56043, partial left frontal (Figure 4.9); IPS 56044 , IPS 56045, ?IPS 56047, fragments of right frontal; ?IPS 56166 (Figure 4.11), partial fused frontal; IPS 59479, fragment of frontal; IPS 56046 (Figure 4.10), fragment of parietal; IPS 56053, fragment of right maxilla with three preserved teeth; IPS 56055, fragment of right dentary with two broken teeth; IPS-56058, fragment of right dentary with one preserved tooth; IPS 56066, anterior region of left dentary with eight preserved teeth.

Apart from dentary and maxillary fragments, a small number of dermal skull elements have been recognized. The frontals and parietals, with the typical lacertid ornamentation, are particularly interesting, and show more than one morphology. Although the bones cannot be referred to a particular taxon with confidence, they do show some potentially significant features. IPS 56043 (Figure 4.9 ) is a small frontal that was clearly one of a pair because of the medial sutural surface. It is relatively wide and has a concave lateral margin. The ornamentation is vermiculate anteriorly, gradually becoming pitted posteriorly. A transverse ridge marks the boundary between the frontal and frontoparietal scales. The posterior margin shows that the frontoparietal suture was strongly interdigitated. The crista cranii is not strongly developed (at least the preserved part), and is pierced by two large foramina. The ornamentation differs from that of the Dormaalisaurus sp. frontal figured in Augé and Smith (2002), which is more uniform and less dense. It is possible, then, that IPS 56043 represents a Gracilicerta frontal, although this cannot be assured. Other more poorly preserved specimens (IPS 56044, IPS 56045, not figured) may represent the same taxon. IPS 56166 (Figure 4.11) is a much larger unpaired frontal. The ornamentation is more uniformly vermiculate than in the smaller frontals, and the bone is much more robust. A transverse groove across the middle of the bone represents the boundary between frontal and frontoparietal scales. Although paired frontals are typical for lacertids, fused frontals occur in several extant taxa where they may be strongly constricted between the orbits (e.g., Acanthodactylus, 
SE pers. obs.) or broad (e.g., Gallotia galloti, Barahona and Barbadillo, 1998: figure 4). Arnold (1989) interpreted frontal fusion in lacertids as resulting from an extension of cranial ontogeny beyond that of primitive taxa. IPS 56166 is very similar to two undescribed specimens from the old collections of the Phosphorites du Quercy (QU 17677, AB pers. obs.) and may represent an additional, large lacertid taxon at Sossís, possibly conspecific with the similar-sized amblyodont dentary (IPS 56169) described above. IPS 56046 (figure 4.10) is a small partial lacertid parietal, which cannot be assigned to one or another taxon. The ornamentation present on this bone is of lacertid type, but as the parietal has not been described for Dormaalisaurus or for Gracilicerta, it is not possible to make a definite referral.

\section{Scincoidea Oppel, 1811 \\ Cordyliformes Fitzinger, 1826}

Although several Paleogene specimens have tentatively been referred to Cordylidae (e.g., Van Dyck, 1983), the presence of cordyliforms (cordylids and gerrhosaurids) in the European Paleogene remains controversial (Augé, 2005). Pseudolacerta, once attributed to Cordylidae (Hecht and Hoffstetter, 1962; Augé, 1990) has now been referred to Iguania (Augé, 2005). A partial postcranial skeleton from the Upper Oligocene of Germany (Rott, MP30, Kempf et al., 1997), initially named 'Lacerta' rottensis (von Meyer, 1856), was attributed to Cordyloidea (=Cordyliformes) by Böhme and Lang (1991), but the specimen is apparently lost (Augé, 2005). However, the middle Eocene Eocordyla mathisi from France is still tentatively referred to the Cordylidae (Augé, 2005), and is of interest as it occurs at levels MP16 and 17 (overlapping in time with Sossís). European Neogene cordylids are recorded from the Miocene of the Czech Republic (Palaeocordylus bohemicus, Dolnice, MN4, Roček, 1984; Merkur-North, MN3, Čerňanský, 2012), Austria (Cordylidae indet., Obergänserndorf 2, MN5; Böhme, 2002), and Germany (Bavaricordylus ornatus, Petersbuch 2, MN4a; Kosma, 2004; Cordylidae indet., Puttenhausen, MN5; Abdul-Aziz et al., 2008; Bavaricordylus molassicus and Cordylidae indet., Sandelzhausen; Böhme, 2010). Although the dental morphology of Bavaricordylus is not conclusively cordyloid, Kosma (2004) based his attribution on the presence of rugosities on the lower jaw related to a covering of osteoderms. Outside Europe, Konkasaurus (Madagascar, latest Cretaceous) has tentatively been referred to Cordylidae, and would represent the earliest known cordyliform (Krause et al., 2003).

\section{Cordyliformes indet.}

Material: IPS 49848, more than 300 body osteoderms (Figure 4.12); and less certainly IPS 56195, anterior (symphyseal region) fragment of left dentary (Figure 4.7) with two preserved teeth.

Description: The osteoderms are rectangular, with an anterior overlapping surface, thin tapering lateral edges, and numerous foramina in the external and internal surfaces. The largest complete osteoderm is $4 \mathrm{~mm}$ long, although some of the broken ones may have been longer. Their width never exceeds $2 \mathrm{~mm}$, but some reach $0.5 \mathrm{~mm}$ in thickness. A small number bear a low, oblique keel. IPS 56195 is an anterior portion of dentary. The preserved teeth have distinct labial and lingual cusps (cuspis labialis and cuspis lingualis, sensu Richter, 1994), and the cuspis lingualis is formed by two apically converging main striae (the stria dominans anterior and posterior, sensu Richter, 1994) at their point of intersection. The lingual surface of the tooth is concave, and bears numerous well-developed striae, some of which seem to bifurcate apically.

Remarks: The osteoderms described herein represent the earliest and most extensive collection available of cordyliform osteoderms from the entire European record. Interestingly, despite the attribution of dental remains from several European localities to cordyliforms, osteoderms are recorded only on two specimens, the lost Oligocene specimen from Rott, Germany, and Miocene material from Obergänserndorf 2, Austria (Böhme, 2010). Given the high preservational potential of osteoderms, due to their numbers and robusticity, the absence of these elements in most Eocene deposits is intriguing. Their small size may render them less likely to be recovered unless the site is intensively screen-washed using fine sieves. The osteoderms of Cordylus and advanced cordylids tend to be spiny, unlike the rectangular elements of the Malagasy Konkasaurus (Krause et al., 2003) or those from Sossís. Richter (1994) gave a detailed review of scincid, gerrhosaurid, and cordylid osteoderms, in relation to those of Mesozoic paramacellodids, concluding that the latter group has compound ventral osteoderms like those of scincids and gerrhosaurids. Those of Konkasaurus, however, showed no evidence of compound structures and the same applies to the Sossís material.

The tooth morphology of IPS 56195 is suggestive of scincoid attribution, but it lacks an antrum intercristatum. In most scincids (and also some lacertids, Kosma, 2004), the cuspis lingualis is not formed by the striae dominantes, but instead 
by a second system of apically converging cutting edges, the crista lingualis anterior and posterior (sensu Kosma, 2004). In these taxa, a sulcus, the antrum intercristatum, may be present between a well-developed cristae lingualis and the labial crista mesialis and distalis. According to Kosma (2004), many cordyliforms and paramacellodids lack an antrum intercristatum, but as it is also missing in some scincids (e.g., Tropidophorus bavaricus from the Miocene of Germany; Böhme, 2010), the character is of restricted value in differentiating members of each group. It is possible that the osteoderms tentatively referred to Cordyliformes (see above) belong to the same taxon as this dentary, but this cannot be demonstrated with the available material. IPS 56195 differs from Eocordyla (Augé, 2005) and also from taxa referred to the Scincidae (Augé, 2005). Had this dentary been found in Mesozoic sediments, it would have probably been attributed to a paramacellodid, supported by the co-occurring rectangular osteoderms, and this highlights a wider problem regarding the status of paramacellodids as a distinct group.

\section{Scincidae Gray, 1825 \\ ?Scincidae indet.}

Material: IPS 56193, ?dentary fragment with five preserved teeth (Figure 4.8); ?IPS 56052, fragment of tooth-bearing bone with one tooth.

Description: The teeth are columnar and very tall, with a slight posterior increase in diameter. A deep antrum intercristatum (sensu Kosma, 2004) is present.

Remarks: The teeth of this second scincoid jaw type differ from those of IPS 56195 described above in having a deep antrum intercristatum, and in lacking lingual striations. The teeth of IPS 56193 are reminiscent of the Paleocene Belgian Scincoideus (Folie et al., 2005), but this taxon has a relatively plesiomorphic dentition.

\section{?Scincoidea Incertae Sedis., Unnamed New Genus and Species}

Two further specimens from Sossís, IPS 56061 (a partial left dentary with two teeth) and IPS 56168 (a fragment of right dentary with one preserved tooth) represent another small taxon with possible scincoid affinities. This will be described and named elsewhere together with similar French material ( $A B$, pers. obs.).

\section{Amphisbaenia Gray, 1844}

Relatively little is known of the fossil history of amphisbaenians in Europe (Augé, 2012). Refer- ences to the presence of the family Amphisbaenidae in the European Paleogene (e.g., Hecht and Hoffstetter, 1962; Augé, 2005) are based mainly on the resemblance of some fossils to the recent genus Blanus, or on the fact that they cannot easily be attributed to any group of 'non-amphisbaenid' amphisbaenians. However, Blanus is now placed in its own family (Blanidae, Kearney, 2003) rather than Amphisbaenidae. Of currently recorded European Paleogene amphisbaenians, the genus Omoiotyphlops from the Phosphorites du Quercy (exact fossil-site unknown, estimated age between latest early Eocene and early Miocene) is a nomen dubium (Estes, 1983: Augé, 2005), and the genus Campinosaurus (Augé, 1992) from Belgium (Dormaal, MP7) is problematic. It is characterized by the presence of striae at the base of the teeth (Augé, 2005), but the only known specimen is a partial dentary with seven preserved tooth positions, making a tooth count of fewer than 10 unlikely. Moreover, with the exception of the striae, the dentary resembles that of the possible scincoid Foliesaurus Augé and Smith, 2009, from the Oligocene of Belgium. Attribution of this material to Amphisbaenia is therefore uncertain. A form close to Blanus has been reported for several Paleogene European sites (e.g., Augé, 2005; Rossmann, 2000 b), but uncertainty regarding the relationships of the living genus complicates referral of the Paleogene remains (Augé, 2005). The German Palaeoblanus, described from the lower Miocene of Weisenau (MN2)(Schleich, 1988) and more tentatively from Gaimersheim (?MP27-28) and Ehrenstein (MP30)(Augé, 2005) is distinguished from the extant Blanus only in the presence of well-developed foramina over the labial surface of the dentary (Augé, 2005), and by the presence of an enlarged first tooth, subtle differences that possibly do not justify its referral to a separate genus. Similarly, the recently described Louisamphisbaena from Grisolles (France, MP16), tentatively referred to Blanidae (Augé, 2012), is difficult to distinguish from Blanus. Indeterminate blanids have been also recently reported from Escamps, St. Néboule (MP18) and Malpérié (Phosphorites du Quercy, France; Augé, 2012). Rossmann (2000b) reported a new amphisbaenian from France (Le Bretou, MP16), but as yet this is unnamed and undescribed. The tentative recognition of the Eocene American genus Anniealexandria in France (Mutigny, MP8-9, Augé, 2012) is problematic. The main diagnostic character is the presence of nine dentary teeth, rather than a maximum of eight as in other amphisbaenians (Smith, 2009a). However, at 


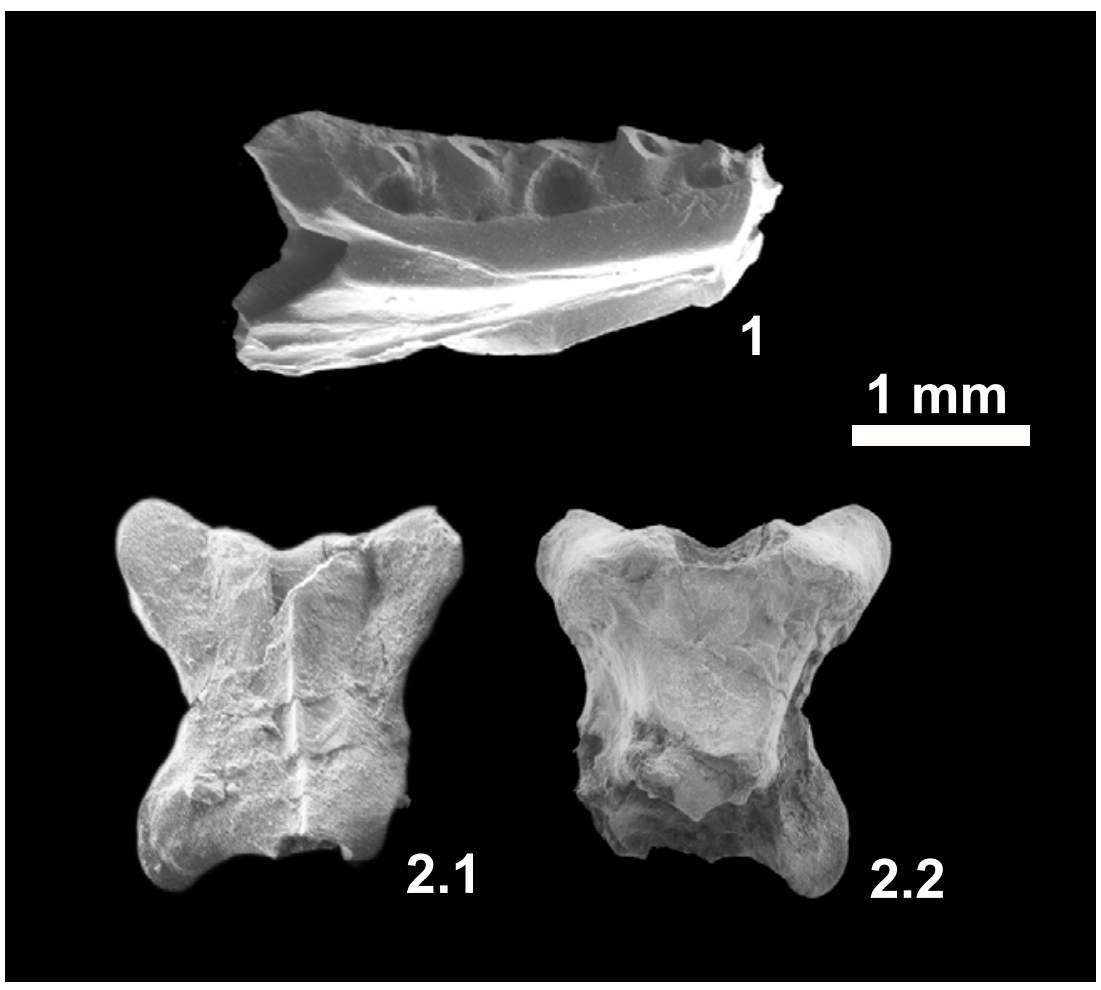

FIGURE 5. Amphisbaenians from the Sossís locality. 1, 2: cf. Blanidae indet. 1- partial left dentary in lingual view (IPS 56062); 2- dorsal vertebra (IPS 56063) in dorsal (2.1) and ventral (2.2) views.

least one specimen of Amphisbaena alba from Bolivia also has nine dentary teeth (Figure 11, p. 1774 in Daza et al., 2011), and the original description of Anniealexandria (Smith, 2009a) noted similarities with Amphisbaena.

\section{cf. Blanidae indet.}

Material: IPS 56062, partial left dentary with five broken teeth (Figure 5.1); IPS 56063, almost complete dorsal vertebra (Figure 5.2); IPS 56064, almost complete dorsal vertebra; IPS 56155, partial dorsal vertebra.

Description: IPS 56062 is lacking its symphyseal region but it is unlikely that more than three or four additional teeth were originally present (tooth count of eight or nine). An intramandibular septum is well-developed, fused to the ventral margin of the dentary, and its posterior edge extends beyond that of the last tooth. Two marked depressions on the dorsolingual and ventrolingual surface of the dentary are interpreted facets for the anterolingual process of the coronoid and the splenial, respectively. Labially (not shown), only the last, particularly large, neurovascular foramen is preserved. Two vertebrae clearly belong to Amphisbaenia. One (IPS 56063) is small and almost complete and the other (IPS 56155) is more poorly preserved. They are strongly dorso-ventrally compressed, lack a neural spine, and have a flat ventral surface to the condyle (preserved only in IPS 56063). Both the condyle and cotyle are widest transversely.

Remarks: As preserved, IPS 56062 is indistinguishable from that of Blanus but given the limited nature of the material, it is possible that it represents a different but closely related genus. We tentatively refer the Sossís material to Blanidae, pending the recovery of more material and the study of additional undescribed amphisbaenian material from Spain (AB pers. obs.) and France. Augé (2012) similarly attributed new material from France to Blanidae based on the strong resemblance of the material to that of the extant genus. The Sossís vertebrae are not diagnostic beyond the level of Amphisbaenia, but they differ from those of Rhineuridae, mainly in the lack of striae over the neural arch.

\section{Anguimorpha Fürbringer, 1900}

Anguimorphs are relatively well-represented in the European Paleogene, mainly by anguids referred to the subfamilies Glyptosaurinae and Anguinae (e.g., Estes, 1983). The extinct Holarctic subfamily Glyptosaurinae is represented in Europe by the glyptosaurin genus Placosaurus from the 


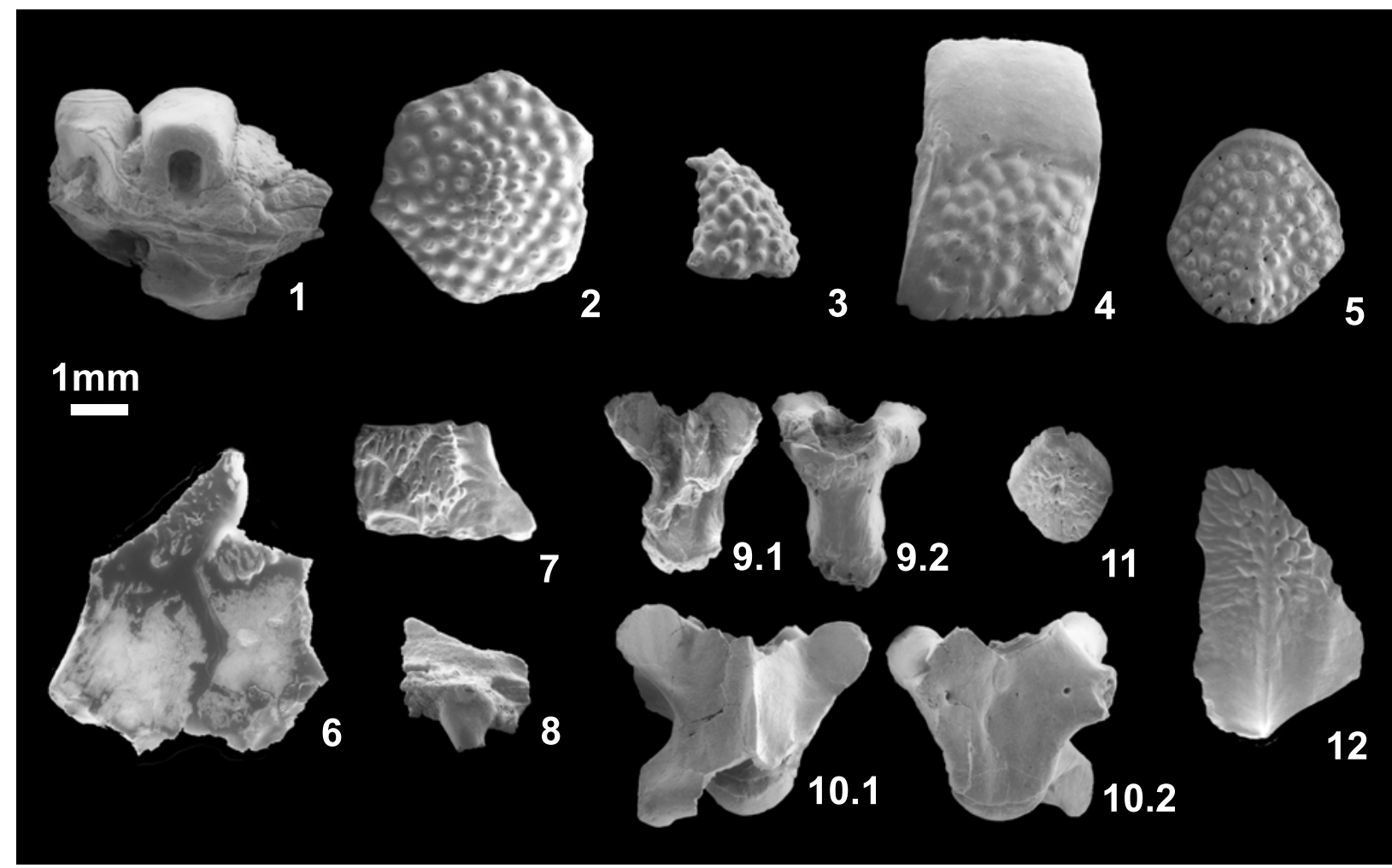

FIGURE 6. Anguimorph specimens from the Sossís locality. 1: Glyptosaurinae indet., fragment of ?dentary (IPS 56167); 2-5: Glyptosaurini indet. 2- hexagonal skull osteoderm in external view (IPS 49845a); 3- skull osteoderm of unusual shape (IPS 49845b). 4- rectangular body osteoderm in external view (IPS 59528); 5- rounded body osteoderm in external view (IPS 49846d); 6-8, 11, 12: Anguinae indet. 6- partial parietal in dorsal view (IPS 56085); 7- posterior region of a right frontal in dorsal view (IPS 56086); 8- fragment of right ?maxilla in lingual view (IPS 56129); 9: Anguinae indet. Form A, vertebra (IPS 56082) in dorsal (9.1) ventral (9.2) views; 10: Anguinae indet. Form B, caudal vertebra (IPS 56080) in dorsal (10.1) and ventral (10.2) views; 11-rounded body osteoderm, in external view (IPS 49851a); 12- elongated body osteoderm, in external view (IPS 49847a).

Eocene of France (La Débruge, MP18; Phosphorites du Quercy, MP 16-19: Sullivan and Augé, 2006) and probably Belgium (Dormaal, MP7: Sullivan et al., 2012), and by the 'melanosaurin' Placosauriops Kuhn, 1940 (France, ?Prémontré, MP10; Germany, Messel and Geiseltal MP11-12), Paraxestops Hoffstetter, 1962 (Switzerland, Mormont-Entreroches, MP19) and Paraplacosauriops Augé and Sullivan, 2006 (France, Phosphorites du Quercy, unknown locality, middle or late Eocene, and Lavergne, MP16: Augé and Sullivan, 2006). Indeterminate specimens of Glyptosaurini (Belgium, England, France, Portugal, and Switzerland; MP8+9 to MP20) and 'Melanosaurini' (France and Portugal, MP7-13) are also recorded from numerous localities across Europe (Augé, 2005). For Anguinae, complete skeletons of Ophisauriscus are known from the middle Eocene of Germany (Kuhn, 1940; Klembara, 1981; Sullivan et al., 1999), whereas Helvetisaurus and Headonhillia are based on disarticulated remains from the late Eocene of Switzerland and France (Augé, 2005), and from England (Headon Hill, Klembara and Green, 2010), respectively. Disarticulated and fragmentary remains from the Eocene and Oligocene have been referred to the extant genera Anguis (France, MP8+9 to MP30; Augé, 2005) and Ophisaurus (Belgium, England, France, and Switzerland ?MP1-5, MP7-30)(Hecht and Hoffstetter, 1962; Augé, 1992; Augé and Smith, 2009; Klembara and Green, 2010). Anguis and Ophisaurus are also recorded from the Neogene, as are representatives of the living Pseudopus, but the latter currently has no Paleogene record (Klembara et al., 2010). Klembara et al. (2010) considered Dopasia to be a synoym of Ophisaurus, as suggested by Sullivan et al. (1999), but later (Klembara and Green, 2010) maintained Dopasia for some Oligocene species. Conrad et al. (2010) also separated Dopasia harti and Pseudopus apodus from Ophisaurus. Anguine 
relationships thus remain incompletely resolved, and this complicates referral of new fossil material.

Anguidae Gray, 1825

Glyptosaurinae Marsh, 1872

Glyptosaurini Sullivan, 1979

Glyptosaurini indet.

Material: IPS 49845a, hexagonal skull osteoderm (Figure 6.2); IPS 49845b, skull osteoderm with unusual shape (Figure 6.3); IPS 49845c, 25 skull osteoderms with unusual shapes; IPS 49845d, $>600$ hexagonal skull osteoderms; IPS 49845e skull osteoderm; 59477, seven skull osteoderms; IPS 59497, two hexagonal skull osteoderms; IPS 59468, hexagonal skull osteoderm; IPS 59485, 28 skull osteoderms; IPS 59508, two skull osteoderms; IPS 59527, 22 worn skull osteoderms. IPS 49846a, body osteoderm; IPS 49846b, >700 body osteoderms; IPS 49846c, >1300 fragments of osteoderm; IPS 49846d, rounded body osteoderm (Figure 6.5); IPS 49846e, rounded body osteoderm; IPS 49846f, 50 rounded body osteoderms; IPS 56068, skull bone fragment with two fused osteoderms; IPS 56069, skull bone fragment with one fused osteoderm; IPS 56070, skull bone fragment with two fused osteoderms; IPS 56071, skull bone fragment with one fused osteoderm; IPS 56072, skull bone with one fused osteoderm; IPS 56073, skull bone with one fused osteoderm; IPS 56075 , skull bone with one fused osteoderm; IPS 59526, skull osteoderm; IPS 59528, body osteoderm.

Description: Thick, tuberculate hexagonal to polygonal skull osteoderms are abundant at Sossís. Irregular osteoderms (with an angular ventral surface or a horn shape) probably represent marginal positions on the skull. Some have worn surfaces so that the typical tubercles have partially or totally disappeared. Body osteoderms are always tuberculate and typically rectangular, with a maximum length of $6 \mathrm{~mm}$. They are bevelled and although they sometimes bear a protuberance formed by tubercles, they are not truly keeled. A few smaller and more rounded (ovoid) osteoderms probably represent osteoderms from the limbs as observed, for example, in Helodermoides (Sullivan, 1979). In these ovoid or rounded osteoderms, the overlap surface is not restricted to the anterior margin but also extends on to the lateral margin.

Remarks: Glyptosaur osteoderms, with the typical tuberculate ornamentation, are the most abundant type within the Sossís osteoderm collection. The hexagonal shape of the skull osteoderms is characteristic of the Glyptosaurini (contra plate-like, non-hexagonal, sub-rectangular to polygonal osteoderms in 'Melanosaurini'; Sullivan, 1979). The Sossís skull osteoderms cannot be differentiated from those of the typical European glyptosaurine Placosaurus, but the attribution of other less diagnostic elements, such as skull bones and body osteoderms, is more tentative. However, nothing points to the presence of a second glyptosaurine (i.e., a 'Melanosaurini').

\section{Glyptosaurinae indet.}

Material: IPS 56167, fragment of ?dentary with two preserved teeth (Figure 6.1); IPS 56149, fragment of ?maxilla with one preserved tooth; IPS 56150 , fragment of maxilla with one preserved tooth.

Description: These jaw fragments bear teeth with labiolingually expanded crowns, that have truncated, almost horizontal occlusal surfaces.

Remarks: These jaw fragments are referred to the Glyptosaurinae on the basis of tooth morphology (robust, labiolingually expanded and square-off tips). A heterodont dentition would be indicative of the presence of 'Melanosaurini' (e.g., Paraplacosauriops), whereas an homodont dentition would suggest Glyptosaurini (e.g., Placosaurus), but the preserved remains are too fragmentary to determine this.

\section{Anguinae Gray, 1825 \\ Anguinae indet.}

Material: IPS 49847a, elongated body osteoderm (Figure 6.12); IPS 49847b, thousands of elongated body osteoderms; IPS 49851a, rounded body osteoderm (Figure 6.11); IPS 49851b, more than 100 rounded body osteoderms; IPS 56082, partial dorsal vertebra (Figure 6.9); IPS 56162, two body osteoderms; IPS 56234, two partial vertebrae; IPS 56085 , posterior fragment of parietal (Figure 6.6); IPS 56086, posterior fragment of a right frontal (Figure 6.7); IPS 56080, dorsal vertebra (Figure 6.10); IPS 56081, 37 partial vertebral centra, condyles showing tendency to be triangular in ventral view; IPS 56083, multiple vertebral condyles; IPS 59486, 30 body osteoderms; IPS 56159, body osteoderm; IPS 56231, three body osteoderms; IPS 59490, four fragments of vertebrae; IPS 59504, vertebra condyle; IPS 59509, three body osteoderms; IPS 59487, two vertebral condyles; and less certainly: IPS 59473, vertebral centrum; IPS 59496, four partial vertebrae; IPS 56128, tooth-bearing bone with one broken tooth; 56129, maxilla fragment with one broken tooth; IPS 56130, anterior fragment of left maxilla; IPS 56136, fragment of left dentary with one broken tooth. 
Description: The osteoderms are typically elongated and keeled, with an ornamentation of pits and ridges. They have an irregular margin but lack a gliding surface. Smaller, ovoid, bevelled osteoderms with the same ornamentation are referred to the same taxon, and represent regional variation on the body. Similar variation occurs in the glyptosaur material. A partial parietal (IPS 56085) is referred to the same taxon, based on the presence of the typical anguine ornamentation consisting of pits and anastomosing grooves. The parietal is small and has a long smooth dorsal surface between the posterior margin of the ornamented surface and the posterior margin of the parietal table (area levis sensu Klembara and Green, 2010). IPS 56128, IPS 56129, IPS 56130, and IPS 56136 are very fragmentary tooth-bearing bones with what seem to be (broken) recurved teeth.

Remarks: The attribution of isolated fragmentary remains of anguines is complicated by the fact that many taxa are represented by isolated material. With the exception of the partial parietal, which shows similarities to that of Headonhillia Klembara and Green, 2010 in the long area levis, the rest of material (including tooth-bearing bones) cannot be identified beyond Anguinae indet. At least two types of anguine osteoderms are present, but as they vary in shape along the different regions of the body, they do not necessarily indicate the presence of two taxa. Vertebrae are equally problematic. It is difficult to differentiate between anguine and glyptosaurine vertebrae, except on the basis of size (e.g., large vertebrae would correspond to glyptosaurines and small vertebrae to anguines, although the boundary is not always clear) and the fact that the ventral surface of the centrum is more flattened in anguines. The two recovered anguid vertebral types are small enough to be referred tentatively to Anguinae, and correspond to the two commonly recognized morphotypes (Rage and Augé, 2010): a derived one (Form A, Figure 6.9) in which the ventral margins of the centrum are parallel (seen only in Anguis), and a more generalised one in which the margins converge towards the condyle, giving a roughly triangular shape (Form $B$, Figure 6.10). The vertebrae of the Franco-Swiss Helvetisaurus are much larger than those from Sossís, and Pseudopus has never been recorded before the Eocene-Oligocene boundary.

\section{Summary of the Sossís Lizard and Amphisbaenian Fauna}

\author{
Iguania \\ Iguanidae \\ Geiseltaliellus pradiguensis \\ Geiseltaliellus sp. \\ Pseudolacerta sp. \\ Gekkota \\ Gekkota indet. Form A \\ Gekkota indet. Form B \\ Gekkota indet. Form C \\ Lacertiformes \\ Lacertidae \\ Dormaalisaurus girardoti \\ Dormaalisaurus rossmanni \\ Gracilicerta sindexi \\ ?Lacertidae indet. (amblyodont form) \\ Scincoidea \\ Cordyliformes \\ Cordyliformes indet. \\ Scincidae \\ ?Scincidae indet. \\ ?Scincoidea incertae sedis, unnamed new genus \\ and species \\ Anguimorpha \\ Anguidae \\ Glyptosaurinae \\ Glyptosaurini \\ Glyptosaurini indet. \\ Glyptosaurinae indet. \\ Anguinae \\ Anguinae indet. Form A \\ Anguinae indet. Form B \\ Amphisbaenia \\ Blanidae \\ cf. Blanidae indet. \\ DISCUSSION
}

\section{Faunal Diversity and Biogeography}

Until now, the only lizard assemblage recorded from the Paleogene of the Iberian Peninsula was that from Silveirinha in Portugal (Rage and Augé, 2003). This early Eocene (MP7) locality has yielded a small but diverse collection of squamate remains including pleurodont and acrodont iguanians, gekkotans, 'scincomorphs', glyptosaurine and anguine anguimorphs, amphisbaenians, and snakes. The Sossís assemblage is younger 
than Silveirinha by more than 17 myr. It is richer in specimen number, but the two localities share a broadly similar herpetofauna that is also comparable to that of more northern European sites. Most Sossís specimens cannot be attributed to named genera, but the lacertids Gracilicerta and Dormaalisaurus, and the iguanian Geiseltaliellus occur both at Sossís and penecontemporaneous French localities (Geiseltaliellus also in Silveirinha). Other taxa (e.g., Pseudolacerta) are found at Sossís and specific French localities (e.g., Malpérié or Escamps). The only major lizard groups missing from Sossís are platynotans (e.g., necrosaurs), melanosaurin glyptosaurines, and acrodont iguanians, although the first of these is present in other Spanish Eocene localities ( $A B$ work in progress and see below). All specimens are small and the glyptosaurs, the largest lizards in the recovered assemblage, are represented by abundant osteoderms but only small fragments of dentition. 'Melanosaurins' have a patchy European distribution, mainly in early and middle Eocene deposits: Paraplacosauriops is reported from Lavergne (MP16) and unknown localities at the Phosphorites du Quercy (Rage, 2012), so the only confirmed record of 'Melanosaurini' in the late Eocene of Europe is Paraxestops (Switzerland, MP19). Acrodont iguanians are recorded from the European early Eocene (MP7-10; Augé, 2005), but appear to have been absent through the middle and most of the late Eocene, despite a reasonably good record of other lizards through this period. Considering the number and diversity of specimens from Sossís, the absence of acrodont taxa is probably not an artifact of sampling.

The Sossís lizard assemblage is diverse, but if it was subject to size-sorting then it probably underestimates the diversity present in the Iberian Peninsula at this time, particularly in relation to larger lizards like platynotans. However, Sossís is not the only new squamate locality on the Iberian Peninsula. Preliminary re-examination of Eocene screen-washing concentrates in the ICP collections shows that squamates were present at many other Spanish localities, although their abundance and diversity is highly variable. These additional localities include further samples from the Southern Pyrenean Basins (from both the Grauss-Tremp and the Ripollès-Berguedà Basins) and Eastern Ebro Basin, as well as others representing the central Iberian basins. Of the latter, the Miranda-Trebiño, Almazán, and Duero Basins form the Western Iberian Bioprovince. Analysis of the Sossís material is thus the first stage in a broader study of Eocene squamate assemblages from the Iberian Peninsula. This will contribute to a more comprehensive understanding of Paleogene European herpetofaunas generally and of the Iberian Peninsula in particular. It could also provide an independent test of biogeographic hypotheses, based mainly on mammals, relating to the degree of faunal interchange between different bioprovinces during the Eocene (e.g., Cuesta, 1991, Badiola, 2004, Badiola et al., 2009). Although the fragmentary nature of the material generally precludes the species-level identifications needed to recognise endemism, it is clear that the Sossís lizard assemblage, pertaining to the Southern-Pyrenean Basin, is similar to that of contemporaneous and near-contemporaneous localities in more northern parts of Europe. Similar observations have been made for artiodactyl mammals from Sossís (Cuesta et al., 2006), and are consistent with the view that middle and early late Eocene mammal faunas (e.g., artiodactyls, perissodactyls, rodents, and primates) from the Southern-Pyrenean Basins are more closely related to those of the rest of Europe than to those from the Western and Central Iberian basins (e.g., CasanovasCladellas and Santafé-Llopis, 1987; Cuesta, 1991; Badiola et al., 2009; Marigó et al., 2010; MinwerBarakat et al., 2012). For most of the Eocene (until at least the earliest late Eocene), the central and western part of the Iberian Peninsula formed an island separated from the rest of Europe, including the Southern-Pyrenean Basins (Badiola et al., 2009, and references therein). Sporadic connections with the rest of the continent would have allowed limited faunal interchanges that would explain the mixture of endemic and widely distributed mammal taxa found in the western and central Iberian basins (e.g., Badiola et al., 2009). Analysis of the squamate assemblages from the different Iberian basins will provide an additional perspective.

\section{Palaeoenvironment}

Ectothermic vertebrates represent a wellestablished proxy indicator in terrestrial palaeoclimatology (Markwick, 1998; Böhme 2003, 2010; Böhme et al., 2006) because they are strongly habitat-dependent. Although a detailed analysis must await study of the remaining herpetofauna, the presence of crocodiles, turtles, frogs, and salamanders together at Sossís suggests mesic conditions (permanent water bodies) and, for at least some of these taxa, high enough temperatures for breeding. Today, most cordyliforms live in open rocky 
environments (Spawls et al., 2002) in Africa and Madagascar, and representatives of this group have been interpreted as among the most thermophilic taxa at the German Miocene locality of Sandelzhausen (Böhme, 2010). The presence of cordylids in Europe during the Miocene is coincident with that of other thermophilous taxa, notably Varanidae, Chamaeleonidae, Tomistomidae, Alligatoridae and giant turtles, probably in relation to the Miocene Climatic Optimum (Böhme, 2003). Similarly, the presence of pleurodont iguanians in the European Eocene is thought to coincide with a warm period that allowed the group to reach higher latitudes and thus disperse from the New World (e.g., Augé, 2005; Smith, 2009a).

Today, 11 extant lizard genera are recorded in Catalonia: two gekkonids, seven lacertids, one anguid, and one scincid (Montori et al., 2010). The amphisbaenian Blanus was present at the southernmost edge of the region, but has not been reported for years. Each of these families was already present at Sossís. However, as at most European Eocene fossil sites (see Augé, 2005; Rage, 2012), it is clear that diversity at Sossís was much higher than that of present-day. This is correlated with the subtropical conditions that existed in Europe during the Eocene (e.g., Rage, 2012) and, by extension, also in the Iberian Peninsula, and it is most striking in the presence of thermophilic iguanians and cordyliforms (plus platynotans at other localities). Amphisbaenians persisted at Catalan Miocene and Pliocene localities, and their current absence (at least north of the Ebro river) could be related to a late (post- Late Pliocene) southward retraction of the group (Blain and Bailon, 2006). Other groups, such as agamids and varanids, progressively disappear during the Pliocene and Pleistocene, not only from the Iberian Peninsula, but from the entirety of Western Europe (Blain and Bailon, 2006).

\section{The Grande Coupure}

The Grande Coupure, defined on the basis of mammals (Stehlin, 1909) and corresponding to the Eocene-Oligocene boundary (MP20-21; SchmidtKittler, 1987), marks the extinction of some lizard groups in Europe and the appearance of others (e.g., Augé, 2005; Rage, 2012). Lizards fall into two groups according to the distributions reported by Augé (2005) and Rage (2012): 1) those present in Europe before the Grande Coupure but which disappear at the boundary (glyptosaurs) and 2) those present in Europe before and after the Grande Coupure. Pleurodont iguanians were con- sidered as absent from Oligocene levels (e.g., Augé, 2005; Rage, 2012), but have been recently reported in the form of Geiseltaliellus sp. from Pech-du-Fraysse (France, MP28, Augé and Pouit, 2012) and Pseudolacerta sp. from Grafenmühle 11 (Germany, MP22-23; Böhme and Ilg, 2003). The second group is heterogeneous in their pattern of survival. Lacertids, for example, have a continuous presence in Europe, but the taxa recorded before and after the Grande Coupure are different at the genus level, with the exception of Plesiolacerta which crosses the boundary but becomes extinct in the early Oligocene. The same is true for necrosaurs and helodermatids. The pleurodont iguanian Geiseltaliellus has been interpreted as a Lazarus taxon, because it is absent from the fossil record for seven standard levels (MP21-27), just to reappear at the MP28 (Augé and Pouit, 2012). Pre- and post-Grande Coupure scincids, cordyliforms and varanids are different and have a less continuous record. Furthermore, they do not fully recover their former range of distribution until the Miocene climate optimum (Böhme, 2003). Anguines seem to have been barely affected by the Grande Coupure, and, despite a poorer record, the same seems to apply to gekkonids and amphisbaenians. Agamids stand apart in that they are present in the early Eocene, disappear for the entire middle and late Eocene, and reappear in the early Oligocene. Thus post-Grande Coupure lizard assemblages were composed of a few survivors (some of which disappeared shortly after) and immigrants with Asian rather than American affinities (Rage, 2012). The lower diversity of Oligocene assemblages in Europe does not seem to be related to an undersampling of Oligocene localities (Smith, 2006). The analysis of late Eocene and Oligocene lizard faunas in the Iberian Peninsula will be particularly interesting as they are geographically intermediate between well-known Central European assemblages and those of Africa, a possible source for at least some of these immigrant taxa (e.g., varanids and cordylids)(Rage, 2012).

\section{CONCLUSIONS}

The new assemblage described here partially fills a gap in our knowledge of Eocene lizard faunas from Europe. Despite the better preservation of specimens from fissure-fillings (e.g., Phosphorites du Quercy) and konservat-lagerstätten (e.g., Messel), the Iberian lizard faunas show a comparable diversity of lizards through the Eocene. The Sossís assemblage is dominated by anguimorphs (glyptosaurs and anguines), scin- 
coids (one cordyliform, one scincid, one indeterminate scincoid), lacertiforms (three or four lacertids), and iguanians, with less abundant gekkotans (probably three taxa) and amphisbaenians. Cordyliform osteoderms represent the first definitive proof of this group in the European Paleogene, possibly with African origins.

\section{ACKNOWLEDGEMENTS}

Our thanks to S. Moyà-Solà (Institut Català de Paleontologia Miquel Crusafont) and the project CGL2011-27343 (Ministerio de Economía y Competitividad, Spain), for providing access to the studied material, and J. Marigó and R. Minwer-Barakat (Institut Català de Paleontologia Miquel Crusafont) for information on Eocene material and localities. We are also indebted to everyone involved in field campaigns. AB's work was supported by FPI grant (BES-2009-026731) and EEBB program associated to the project CGL2008-06533-C03-01/BTE, and by the project CGL2011-30069-C02-01 (Ministerio de Ciencia e Innovación, Spain). C. Mehling and M. Norell at the American Museum of Natural History (New York) and J.C. Rage at the Museum National d'Histoire Naturelle (Paris) kindly assisted $A B$ in his visit to their respective institutions. We appreciate the constructive suggestions made by three anonymous reviewers.

\section{REFERENCES}

Abdul-Aziz, H., Böhme, M., Rocholl, A., Zwing, A., Prieto, J., Wijbrans, J., Heissig, K., and Bachtadse, V. 2008. Integrated stratigraphy of the Early to Middle Miocene Upper Freshwater Molasse in Lower Bavaria (Germany, Bavaria). International Journal of Earth Sciences (Geologische Rundschau), 97:115134.

Arnold, E.N. 1989. Towards a phylogeny and biogeography of the Lacertidae: relatinships within an OldWorld family of lizards derived from morphology. Bulletin of the British Museum of (Natural History) Zoology, 55:209-257.

Augé, M. 1987. Confirmation de la présence d'Iguanidae (Reptilia, Lacertilia) dans l'Eocène européen. Comptes Rendus de l'Académie des Sciences, Paris, 305:633-636.

Augé, M. 1990. La faune de lézards et d'amphisbènes (Reptilia, Squamata) du gisement de Dormaal (Belgique, Éocène inférieur). Bulletin de l'Institut royal des Sciences naturelles de Belgique, Sciences de la Terre, 60:161-173.

Augé, M. 1992. Une espèce nouvelle d'Ophisaurus (Lacertilia, Anguidae) de l'Oligocène des Phosphorites du Quercy. Révision de la sous-famille des Anguinae. Paläontologische Zeitschrift, 66:159-175.
Augé, M. 2003. La faune de Lacertilia (Reptilia, Squamata) de l'Éocène inférieur de Prémontré (Bassin de Paris, France). Geodiversitas, 25:539-574.

Augé, M. 2005. Évolution des lézards du Paléogène en Europe. Mémoires du Muséum national d'Histoire naturelle, Paris, 192.

Augé, M. 2007. Past and present distribution of iguanid lizards. Arquivos do Museu Nacional, Rio de Janeiro, 65:403-416.

Augé, M. 2012. Amphisbaenians from the European Eocene: a biogeographical review. Palaeobiodiversity and Palaeoenvironments, 92:425-443.

Augé, M. and Hervet, S. 2009. Fossil lizards from the locality of Gannat (late Oligocene-early Miocene, France) and a revision of the genus Pseudeumeces (Squamata, Lacertidae). Palaeobiodiversity and Palaeoenvironments, 89:191-201.

Augé, M. and Pouit, D. 2012. Presence of iguanid lizards in the European Oligocene Lazarus taxa and fossil abundance. Bulletin de la Société Géologique de France, 183:653-660.

Augé, M. and Smith, R. 2002. Nouveaux Lacertidae (Reptilia, Squamata) de l'Eocène inférieur européen. Belgian Journal of Zoology, 131:3-15.

Augé, M. and Smith, R. 2009. An assemblage of early Oligocene lizards (Squamata) from the locality of Boutersem (Belgium), with comments on the Eocene-Oligocene transition. Zoological Journal of the Linnean Society, 155:148-170.

Augé, M. and Sullivan, R.M. 2006. A new genus, Paraplacosauriops (Squamata, Anguidae, Glyptosaurinae), from the Eocene of France. Journal of Vertebrate Paleontology, 26:133-137.

Badiola, A. 2004. Estudio paleontológico del yacimiento del Eoceno Superior de Zambrana (Álava, región Vasco-Cantábrica). Tafonomía, paleobiología de mamíferos e implicaciones biocronológicas. Unpublished PhD Thesis, Universidad del País Vasco, Spain.

Badiola, A., Checa, L., Cuesta, M.A., Quer, R., Hooker, J.J., and Astibia, H. 2009. The role of new Iberian finds in understanding European Eocene mammalian paleobiogeography. Geologica Acta, 7:243-258.

Barahona, F. and Barbadillo, L.J. 1998. Inter- and intraspecific variation in the post-natal skull of some lacertid lizards. Journal of Zoology, 245:393-405.

Berg, D.E. and Crusafont, M. 1970. Note sur quelques Crocodiliens de l'Eocène prépyrénaïque. Acta Geologica Hispanica, 5:54-57.

Blain, H.-A. and Bailon, S. 2006. Catalogue of Spanish Plio-Pleistocene amphibians and squamate reptiles from the Museu de Geologia de Barcelona. Treballs del Museu de Geologia de Barcelona, 14:61-80.

Böhme, M. 2002. Lower Vertebrates (Teleostei, Amphibia, Sauria) from the Karpatian of the Korneuburg Basin - palaeoecological, environmental and palaeoclimatical implications. Beiträge zur Paläontologie, 27:339-354. 
Böhme, M. 2003. The Miocene climatic optimum: evidence from ectothermic vertebrates of Central Europe. Palaeogeography, Palaeoclimatology, Palaeoecology, 195:389-401.

Böhme, M. 2010. Ectothermic vertebrates (Actinopterygii, Allocaudata, Urodela, Anura, Crocodylia, Squamata) from the Miocene of Sandelzhausen (Germany, Bavaria) and their implications for environment reconstruction and palaeoclimate. Paläontologische Zeitschrift, 84:3-41.

Böhme, M. and Ilg, A. 2003. fosFARbase, www.wahrestaerke.com/ (access date: September 2012).

Böhme, W. and Lang, M. 1991. The reptilian fauna of the Late Oligocene locality Rott near Bonn (Germany) with special reference to the taxonomic assignment of "Lacerta" rottensis von Meyer, 1856. Neues Jahrbuch für Geologie und Paläontologie, Monatshefte, 9:515-525.

Böhme, M., Ilg, A., Ossig, A., and Küchenhoff, H. 2006. A new method to estimate paleoprecipitation using fossil amphibians and reptiles and the Middle and Late Miocene precipitation gradients in Europe. Geology, 34:425-428.

Bonaparte, C.L.J.L. 1831. Saggio di una distribuzione metodica degli animali vertebrati. Antonio Boulzaler, Rome.

Borsuk-Białynicka, M., Lubka, M., and Böhme, W. 1999. A lizard from Baltic amber (Eocene) and the ancestry of the crown group lacertids. Acta Palaeontologica Polonica, 44:349-382.

Boulenger, G.A. 1917. A revision of the lizards of the genus Nucras, Gray. Annals of the South African Museum, 13:95-215.

Casanovas, M.L., Checa, LI., and Santafé, J.V. 1998. Los perisodáctilos del yacimiento ludiense de Sossís (Cuenca Prepirenaica, Lleida, España), p. 235-265. In López-Martínez N., Civis, M.L., CasanovasCladellas, M.L., and Daams, R. (eds.), Geología y Paleontología del Eoceno de la Pobla de Segur. Universitat de Lleida, Lleida.

Casanovas-Cladellas, M.L. and Santafé-Llopis, J.V. 1987. Cantabrotherium truyolsi nov. gen. nov. sp. (Palaeotheriidae, Perissodactyla) un exemple d'endémisme dans le Paléogène ibérique. Münchner Geowissenschaftliche Abhandlungen (A), 10:243252.

Čerňanský, A. 2012. The oldest known European Neogene girdled lizard fauna (Squamata, Cordylidae), with comments on Early Miocene immigration of African taxa. Geodiversitas, 34:837-848.

Checa, LI. and Casanovas, M.L. 1990. El Eoceno español: los yacimientos y sus faunas. Paleontologia i Evolució, 23:17-39.

Conrad, J.L. 2008. Phylogeny and systematics of Squamata (Reptilia) based on morphology. Bulletin of the American Museum of Natural History, 310:1-182.
Conrad, J.L., Ast, J.C., Montanari, S., and Norell, M.A. 2010. A combined evidence phylogenetic analysis of Anguimorpha (Reptilia: Squamata). Cladistics, 26:148.

Crusafont, M. 1965. Los Mamíferos, y en especial los Primates del Eoceno prepirenaico. Notas y Comunicaciones del Instituto Geológico y Minero de España, 78:159-166.

Crusafont, M. 1967. Sur quelques prosimiens de l'Eocène de la zone préaxiale pyrénaïque et un essai provisoire de reclassification. Colloques Internationaux de Centre National de la Recherche Scientifique, 163:611-632.

Crusafont, M. and Golpe-Posse, J.M. 1974. Primates fósiles de España. Miscellanea Alcobé, 1974:29-44.

Cuenca-Bescós, G. 1998. Los Pseudoesciúridos (Rodentia) del Eoceno Superior de la cuenca lacustre de Sossís (Pirineos), p. 181-233. In LópezMartínez , Civis, M.L., Casanovas-Cladellas, M.L., and Daams, R. (eds.), Geología y Paleontología del Eoceno de la Pobla de Segur. Universitat de Lleida, Lleida.

Cuesta Ruíz-Colmenares, M.A. 1991. Perisodáctilos del Eoceno de la Cuenca del Duero. Unpublished Ph.D. Thesis, Universidad de Salamanca, Salamanca, Spain.

Cuesta Ruíz-Colmenares, M.A., Checa Soler, L., and Casanovas-Cladellas, M.L. 2006. Artiodáctilos del yacimiento de Sossís (Eoceno superior, Cuenca Prepirenaica, Península Ibérica). Revista Española de Paleontología, 21:123-144.

Cuvier, G. 1817. Le regne animal distribué d'après son organisation, pour servir de base a l'histoire naturelle des animaux et d'introduction a l'anatomie comparée. Paris.

Daza, J.D., Diogo, R., Johnston, P., and Abdala, V. 2011. Jaw adductor muscles across lepidosaurs: a reappraisal. The Anatomical Record, 294:1765-1782.

De Stefano, G. 1903. I sauri del Quercy appartenenti alla collezione Rossignol. Atti della Societa Italiana di Scienze Naturali e del Museo Civico di Storia Naturale in Milano, 42:382-418.

Estes, R. 1983. Sauria, Amphisbaenia, p. 1-249. In Wellnhofer, P. (ed.), Handbuch der Palaeoherpetologie, Vol. 10A. Gustav Fischer Verlag, Stuttgart.

Estes, R., de Queiroz, K., and Gauthier, J. 1988. Phylogenetic relationships within Squamata, p. 119-281. In Estes, R. and Pregill, G. (eds.), Phylogenetic relationships of the lizard families. Stanford University Press, Stanford.

Evans, S.E. 2008. The skull of lizards and tuatara, p. 1344. In Gans, C., Gaunt, A.S. and . Adler, K. (eds.), Biology of the Reptilia, vol. 20: Morphology $\mathrm{H}$, The skull of Lepidosauria, 1-344. Ithaca, Society for the Study of Amphibians and Reptiles, New York.

Filhol, H. 1877. Recherches sur les Phosphorites du Quercy. Pt. II. Annales Sciences Géologiques, 8:1338. 
Filhol, H. 1882. Description d'un genre nouveau de reptile fossile. Bulletin de la Société Philomatique, Paris, 6:127.

Fitzinger, L.I. 1826. Neue classification der Reptilien nach ihren natürlichen Verwandtschaften nebst einer verwandts-tafel und einem verzeichnisse der reptilien-sammlung des k.k. zoologischen museum zu Wien. Heubner, J.G., Wien.

Folie, A., Sigé, B., and Smith, T. 2005. A new scincomorph lizard from the Palaeocene of Belgium and the origin of Scincoidea in Europe. Naturwissenschaften, 92:542-546.

Fürbringer, M. 1900. Zur vergleichenden anatomie des Brustschulterapparates und der Schultermuskeln. Jenaische Zeitschrift, 34:215-718.

Gauthier, J.A., Kearney, M., Maisano, J.A., Rieppel, O., and Behlke, D.B. 2012. Assembling the squamate tree of life: perspectives from the phenotype and the fossil record. Bulletin of the Peabody Museum of Natural History, 53:3-308.

Gray, J.E. 1825. A synopsis of the genera of reptiles and amphibia, with a description of some new species. Thomson annals of Philosophy, London, 10:193-217.

Gray, J.E. 1827. A synopsis of the genera of saurian reptiles, in which some new genera are indicated and the others reviewed by actual examination. Annals of Philosophy, New Series, 2:54-58.

Gray, J.E. 1844. Catalogue of the tortoises, crocodiles, and amphisbaenians in the collection of the British Museum. British Museum of Natural History, London.

Hecht, M.K. and Hoffstetter, R. 1962. Note préliminaire sur les Amphibiens et les Squamates du Landenien supérieur et du Tongrien de Belgique. Bulletin de I'Institut Royal des Sciences Naturelles de Belgique, 39:1-30.

Hoffstetter, R. 1944. Sur les Scincidae fossils. I. Formes européenes et nord-américaines. Bulletin $d u$ Muséum National d'Histoire Naturelle, Paris, 16:547553.

Hoffstetter, R. 1946. Sur les Gekkonidae fossiles. Bulletin du Muséum National d'Histoire Naturelle, 18:195203.

Hoffstetter, R. 1962. Additions a la faune reptilienne de l'Eocène superieur de Mormont-Saint-Loup (Suisse). Bulletin de la Société Géologique de France, 7:149157.

Kearney, M. 2003. Systematics of the Amphisbaenia (Lepidosauria: Squamata) based on morphological evidence from recent and fossil forms. Herpetological Monographs, 17:1-74.

Kempf, O., Bollinger, T., Kälin, D., Engesser, B., and Matter, A. 1997. New magnetostratigraphic calibration of Early to Middle Miocene mammal biozones of the North Alpine Foreland Basin, p. 547-561. In Aguilar, J.P., Legendre, S., and Michaux, J. (eds.). Actes du Congres Biochron '97. Mem. Trav. E.P.H.E.. Inst. Montpellier 21.
Klembara, J. 1981. Beitrag zur Kenntnis der Subfamilie Anguinae (Reptilia, Anguidae). Acta Universitatis Carolinae - Geologica (Praha), 2:121-168.

Klembara, J. and Green, B. 2010. Anguimorph lizards (Squamata, Anguimorpha) from the Middle and Late Eocene of the Hamphsire Basin of Southern England. Journal of Systematic Palaeontology, 8:97129.

Klembara, J., Böhme, M., and Rummel, M. 2010. Revision of the anguine lizard Pseudopus laurillardi (Squamata, Anguidae) from the Miocene of Europe, with comments on paleoecology. Journal of Paleontology, 84:159-196.

Kosma, R. 2004. The dentitions of recent and fossil scincomorphan lizards (Lacertilia, Squamata) - Systematics, Functional Morphology, Palecology. Unpublished PhD Thesis, University of Hannover. Digital publication, University of Hannover website: www.tib.uni-hannover.de/DigitaleBibliothek/Elektronische Hochschulschriften.html.

Krause, D.W., Evans, S.E., and Gao, K.-Q. 2003. First definitive record of Mesozoic lizards from Madagascar. Journal of Vertebrate Paleontology, 23:842-856.

Kuhn, O. 1940. Die Placosauriden und Anguiden aus dem mittleren Eozän des Geiseltales. Nova Acta Leopoldina, 8:461-486.

Kuhn, O. 1944. Weitere Lacertilier, insbesondere Iguaniden aus dem Eozän des Geiseltales. Paläontologische Zeitschrift, 23:360-366.

López-Martínez, N., Civis, J., Casanovas, L., and Daams, R. 1998. Geología y Paleontología del Eoceno de la Pobla de Segur (Lleida). Edicions de la Universitat de Lleida, Lleida.

Marigó, J., Minwer-Barakat, R., and Moyà-Solà, S. 2010. A new Anchomomyni (Adapoidea, Primates) from the Mazaterón Middle Eocene locality (Almazán Basin, Soria, Spain). Journal of Human Evolution, 58:353361.

Marigó, J., Minwer-Barakat, R., and Moyà-Solà, S. In press. Nievesia sossissensis, a new anchomomyin (Adapiformes, Primates) from the early Late Eocene of the southern Pyrenees (Catalonia, Spain). Journal of Human Evolution. Doi: 10.1016/j.jhevol.2012.11.004.

Markwick, P.J. 1998. Fossil crocodilians as indicators of Late Cretaceous and Cenozoic climates: implication for using paleontological data in reconstructing palaeoclimate. Palaeogeography, Palaeoclimatology, Palaeoecology, 137:205-271.

Marsh, O.C. 1872. Preliminary description of new Tertiary reptiles. Parts I and II. American Journal of Science, 101:447-458.

Minwer-Barakat, R., Marigó, J., and Moyà-Solà, S. 2012. Pseudoloris cuestai, a new microchoerine (Primates, Omomyidae) from the Middle Eocene of the Iberian Peninsula. Journal of Vertebrate Paleontology, 32:407-418. 
Montori, A., Santos, X., Sancho, V., Mayol, J., Lacomba, J.I., Llorente, G.A., and Franch, M. 2010. Consideracions generals sobre la fauna de rèptils $p$. 327348. In Giralt i Radigales, J., Comelles, M., Montagud, Ė., Comín, P., Vigo, M., Puig, B., Ferrand, À., and Bosch, P. (eds.), Història Natural dels Països Catalans. Fauna i flora supplement. Enciclopèdia Catalana, Barcelona.

Müller, J., Hipsley, C.A., Head, J.J., Kardjilov, N., Hilger, A., Wuttke, M., and Reisz, R.R. 2011. Eocene lizard from Germany reveals amphisbaenian origins. Nature, 473:364-367.

Oppel, M. 1811. Die Ordnung, Familien und Gattungen der Reptilien als Prodrom einer Naturgeschichte derselben. Lindauer, München.

Peláez-Campomanes, P. 1998. Estudio sistemático del género Theridomys (Rodentia, Mammalia) del Eoceno Superior de la cuenca prepirenaica (provincia de Lleida), p. 49-129. In López Martínez, N., Civis, J., Casanovas-Cladellas, L., and Daams, R. (eds.), Geología y Paleontología del Eoceno de la Pobla de Segur (Lleida). Edicions de la Universitat de Lleida, Lleida.

Pomel, A. 1846. Mémoire pour servir à la géologie paléontologique des terrains tertiares du département de l'Allier. Bulletin de la Société Géologique de France, 3:353-373.

Rage, J.C. 2012. Amphibians and squamates in the Eocene of Europe: what do they tell us?. Palaeobiodiversity and Palaeoenvironments, 92: 445-457.

Rage, J.C. and Augé, M. 2003. Amphibians and squamate reptiles from the lower Eocene of Silveirinha (Portugal). Ciências da Terra (UNL), 15:103-116.

Rage, J.C. and Augé, M. 2010. Squamate reptiles from the middle Eocene of Lissieu (France). A landmark in the middle Eocene of Europe. Geobios, 43:253-268.

Richter, A. 1994. Lacertilia aus Unteren Kreide von Uña und Galve (Spanien) und Anoual (Marokko). Berliner Geowissenschaftliche Abhandlungen A, 14:1-147.

Roček, Z. 1984. Lizards (Reptilia: Sauria) from the Lower Miocene locality Dolnice (Bohemia, Czechoslovakia). Rozpravy Československé Akademie Věd, 94(1):169.

Rossmann, T. 2000a. Osteologische Beschreibung von Geiseltaliellus longicadus Kuhn, 1944 (Squamata: Iguanoidea) aus dem Mittleren Eozän der Fossillagerstätten Geiseltal und Grube Messel (Deutschland) mit einer Revision der Gattung Geiseltaliellus. Palaeontographica A, 258:117-158.

Rossmann, T. 2000b. A new Amphisbaenian (Squamata) from the Phosphorites du Quercy, France. 5 th European Workshop on Vertebrate Palaeontology, Abstracts, Karlsruhe.

Schleich, H.H. 1988. Neue Reptilienfunde aus dem Tertiär Deutschlands 8. Palaeoblanus tobieni n. gen., n. sp. - neue Doppelschleichen aus dem Tertiär Deutschlands. Paläontologische Zeitschrift, 62:95105.
Schmidt-Kittler, N. 1987. International Symposium on Mammalian Bioestratigraphy and Paleoecoloy of the European Paleogene. Münchner Geowissenschaftliche Abhandlungen (A), 10:1-311.

Sigé, B. 1997. Les mammifères insectivores des nouvelles collections de Sossís et sites associés (Éocène Supérieur, Espagne). Geobios, 30:91-113.

Smith, K.T. 2006. A diverse new assemblage of late Eocene squamates (Reptilia) from the Chadron Formation of North Dakota, U.S.A. Palaeontologia Electronica, 9:1-44.

Smith, K.T. 2009a. A new lizard assemblage from the earliest Eocene (zone Wa0) of the Bighorn Basin, Wyoming, USA: biogeography during the warmest interval of the Cenozoic. Journal of Systematic Palaeontology, 7:299-358.

Smith, K.T. 2009b. Eocene Lizards of the Clade Geiseltaliellus from Messel and Geiseltal, Germany, and the Early Radiation of Iguanidae (Reptilia: Squamata). Bulletin of the Peabody Museum of Natural History, 50:219-306.

Smith, K.T. 2011. The Evolution of Mid-latitude Faunas during the Eocene: Late Eocene Lizards of the Medicine Pole Hills Reconsidered. Bulletin of the Peabody Museum of Natural History, 52(1):3-105.

Spawls, S., Howell, K., Drewes, R., and Ashe, J. 2002. A field guide to the Reptiles of East Africa. Academic, San Diego, California.

Stehlin, H.G. 1909. Remarques sur les faunules de mammifères des couches éocènes et oligocènes du Bassin de Paris. Bulletin de la Societé Géologique de France, 9:488-520.

Sullivan, R.M. 1979. Revision of the Paleogene genus Glyptosaurus (Reptilia, Anguidae). Bulletin of the American Museum of Natural History, 163:1-72.

Sullivan, R.M. and Augé, M. 2006. Redescription of the holotype of Placosaurus rugosus Gervais 1848-1852 (Squamata, Anguidae, Glyptosaurinae) from the Eocene of France and a revision of the genus. Journal of Vertebrate Paleontology, 26:127-132.

Sullivan, R.M., Keller, T., and Habersetzer, J. 1999. Middle Eocene (Geiseltalian) anguid lizards from Geiseltal and Messel, Germany. I. Ophisauriscus quadrupes Kuhn 1940. Courier Forschungsinstitut Senckenberg, 216:97-129.

Sullivan, R.M., Augé, M., Wille, E., and Smith, R. 2012. A new glyptosaurine lizard from the earliest Eocene of Dormaal, Belgium. Bulletin de la Société Géologique de France, 183:627-633.

Townsend, T.M., Larson, A., Louis, E., and Macey, J.R. 2004. Molecular phylogenetics of Squamata: the position of snakes, amphisbaenians, and dibamids, and the root of the squamate tree. Systematic Biology, 53:735-757.

Van Dyck, M.-C. 1983. Etude de la faune herpétologique du "Montien" continental de Hainin (Hainaut, Belgique) et d'autres gisements paleogènes du NordOuest de l'Europe. Unpublished PhD Thesis, Université Catholique de Louvain, Belgique. 
Vicario, S., Caccone, A., and Gauthier, J. 2003. Xantusiid "night" lizards: a puzzling phylogenetic problem revisited using likelihood-based Bayesian methods on mtDNA sequences. Molecular Phylogenetics and Evolution, 26:243-261.

Vidal, N. and Hedges, S.B. 2005. The phylogeny of squamate reptiles (lizards, snakes, and amphisbaenians) inferred from nine nuclear protein-coding genes. Comptes Rendus Biologies, 328:1000-1008.

von Meyer, H. 1856. Letter on various fossil vertebrates. Neues Jahrbuch für Mineralogie Geologie und Paläontologie, 1856:824-829.

Wiens, J.J., Brandley, M.C., and Reeder, T.W. 2006. Why does a trait evolve multiple times within a clade? Repeated evolution of snake-like body form in squamate reptiles. Evolution, 61:123-141.
Wiens, J.J., Kuczynski, C.A., Townsend, T., Reeder, T.W., Mulcahy, D.G., and Sites, J.W. Jr. 2010. Combining phylogenomics and fossils in higher level squamate reptile phylogeny: molecular data change the placement of fossil taxa. Systematic Biology, 59:674-688.

Wiens, J.J., Hutter, C.R., Mulcahy, D.G., Noonan, B.P., Townsend, T.M., Sites, J.W. Jr, and Reeder, T.W. 2012. Resolving the phylogeny of lizards and snakes (Squamata) with extensive sampling of genes and species. Biology Letters, online publication, doi:10.1098/rsbl.2012.0703. 